\title{
A Pedagogical Model to Educate Tomorrow's Engineers through a Cloud- based Design and Manufacturing Infrastructure - Motivation, Infrastructure, Pedagogy, and Applications
}

\author{
Mr. Srujal Patel, Georgia Institute of Technology \\ Dr. Dirk Schaefer, Georgia Institute of Technology
}

Prof. Dirk Schaefer serves on the faculty of the George W. Woodruff School of Mechanical Engineering at the Georgia Institute of Technology. Prior to joining Georgia Tech, Dr. Schaefer was a Lecturer in the School of Engineering at Durham University, UK. During his time at Durham, he earned a Postgraduate Certificate in "Teaching and Learning in Higher Education". He joined Durham from a Senior Research Associate position at Stuttgart University, Germany, where he earned his Ph.D. in Computer Science. Over the past 15 years, Dr. Schaefer has conducted research on product modeling, variant design, product lifecycle management, design-with-manufacture integration, standardized product data exchange, as well as digital and virtual engineering. His current research focus concerns the highly topical area of Cloudbased Design and Manufacturing (CBDM). A passionate educator, Dr. Schaefer also conducts research on Design Education, Personalized Learning, Distance Learning, and Professional Faculty Development. He has published more than 120 technical papers on Computer-Aided Engineering \& Design as well as Engineering Education, and has presented his work at numerous national and international conferences, symposia, and workshops around the world. Dr. Schaefer serves as editorial advisory board member and reviewer for several international journals in his field. In addition, he is a registered Professional Engineer in Europe (Eur Ing), a Chartered Engineering (CEng), a Chartered IT Professional (CITP), and a Fellow of the Higher Education Academy (FHEA) in the UK, as well as registered International Engineering Educator (Ing-Paed IGIP).

Dr. Daniel P. Schrage, Georgia Institute of Technology 


\section{A pedagogical model to educate tomorrow's engineers through a cloud-based Design and Manufacturing Infrastructure}

\section{Motivation}

Encouraging high school students to pursue a career in Engineering is crucial in building a strong foundation for a successful future of any nation. The United States is ranked 27th (out of 29) for the rate of Science, Technology, Engineering \& Mathematics (STEM) bachelor's degrees awarded in developed countries - $6 \%$ of U.S. undergraduates major in engineering compared with $12 \%$ in Europe, $20 \%$ in Singapore, and $40 \%$ in China ${ }^{1}$. In order to increase the number of engineering graduates, it is important to encourage and motivate more adolescent learners to pursue careers in Engineering. Recently multiple initiatives have been undertaken to raise interest in STEM education in the United States ${ }^{2,3}$. Many of these initiatives are outreach programs to engage high school students in projects which focus on cultivating their aptitude in STEM related disciplines. Most of these programs appear to be focused more on Science or Mathematics rather than on Engineering and Technology (besides the use of computers) ${ }^{4}$. Even in those rare K-12 outreach programs where Engineering is the primary area of focus, it is usually introduced through problems or activities related to the application fields of Robotics, Manufacturing, Computer-aided-design (CAD) etc. Most of these discipline-focused initiatives fall short in terms of providing a more holistic experience of Engineering as a unified discipline. The main reason for this is that the inherent complexity involved in integrating multiple disciplines into a project over a relatively short period of time is a major challenge. So colloquially speaking, oftentimes students don't get to see the forest for the tree. As a result many students lose their curiosity to learn more about the engineering profession and decide to choose a different career path.

To address these concerns, an innovative teaching model based on a structured curriculum is proposed to not only introduce students to multiple engineering disciplines but also allow them to be part of a unified engineering experience through an engineering-based product development capstone project that also incorporates the key principles of systems engineering. This teaching model is delivered via an Integrated Design \& Manufacturing Infrastructure (IDMI), which incorporates virtual resources, such as Computer-Aided Design (CAD) systems, as well as physical resources, such as additive manufacturing machines like 3D printers. The model utilizes a cloud computing-based IT infrastructure for collaborative, distributed engineering and can be implemented at either high school or undergraduate freshmen level to introduce students to a variety of Engineering Design related activities in a holistic fashion.

In Section 1, a brief overview of the key elements of the teaching model is provided to demonstrate how various Engineering disciplines are seamlessly interlaced in the project-based curriculum. Section 2 addresses how IDMI fosters the symbiosis and integration of virtual and physical resources to facilitate delivering the teaching model proposed in Section 1. In addition, a number of potential ways of implementing this model locally at one campus or in a nationwide distributed setting are proposed. Section 3 provides an overview of a prototype implementation 
of the model tested in a high school summer camp program that was conducted concurrently at two geographical locations. In this section, experiences and lessons learned from this endeavor are summarized and conclusions are drawn through formative assessment activities conducted during the summer camp. Solutions are proposed to rectify identified issues or challenges that were faced in this prototype case-study. In Section 4, we provide a summary and comment on our plans for future work.

\section{Pedagogical Model}

Through the proposed model we are trying to accomplish following learning objectives:

a. Provide students with a view of Engineering as a unified profession and introduce them to key systems engineering principles.

b. Introduce students to the product lifecycle and enhance their intuition of how today's engineers use principles of Science and Mathematics to develop a product by sequentially and systematically following different stages of the product design lifecycle.

c. Provide students an opportunity to develop and utilize their imagination and ideation skills.

d. Introduce students to key principles of modern manufacturing.

e. Develop students' teamwork and communications skills by fostering collaboration.

f. Familiarize students with select state-of-the-art technology today's engineers use in their profession.

\section{The Prize Challenge structure}

Our pedagogical model is anchored in a team-based product development project or "prize challenge". In the prize challenge, each team is required to appoint a mentor or team leader, for example a STEM teacher or a professional engineer, who provides professional guidance as the team proceeds through the entire prize challenge. The prize challenge requires students to select a design concept for a customizable component of a moderately complex electromechanical system that can be built and assembled. Once students have selected a principal design concept they wish to pursue, they are required to generate a realistic 3D model of the part in a commercial professional Computer aided Design (CAD) software environment. Students also use 3D printers to create physical prototypes of their designs and then assemble the printed parts, integrate them within a given engineering system and operate the system to perform the mission stated in the challenge. Through the challenge, students go through different stages of the product development life cycle. These stages are identified as Cocreate, Design, Build \& Operate (CDBO), and represent a specific implementation of what is known as $\mathrm{CDIO}^{5}$ on a broader context. 


\section{The Curriculum}

A curriculum developed to deliver our approach functions as a stepping stone for students to gain the skills required to successfully participate in our prize challenges. The curriculum also contains tutorials which are organized in 'learning modules'. Alphabets in brackets at the end of each module name relate to the corresponding learning objectives stated above.

i. Introduction to Product Lifecycle Management. (a, b)

ii. Introduction to Systems Engineering Principles using moderately complex ElectroMechanical Systems. (a, b)

iii. Computer Aided Design using Dassault Systemes CATIA V6. (b, c, f)

iv. Additive Manufacturing using 3D printers $(b, d)$

v. Collaborative Tools $(\mathrm{a}, \mathrm{b}, \mathrm{e}, \mathrm{f})$

Tutorials are available in various formats ranging from tutorial guides, to animation videos and prerecorded short lectures. Tutorials are designed in such a way that students can follow them without any assistance and at their own pace. In order to tightly couple the modules with our learning objectives, the Wiggins \& McTighe ${ }^{6}$ curriculum-design template was used (please see Appendix A for details).

The following section discusses the details of each module:

\section{i. Introduction to Product Lifecycle Management}

The prize challenges require students to go through the key stages of the entire product lifecycle, which begins at conceptual design and culminates in a fully operational product. Before students participate in the challenge, it is important that they understand the various stages of the product development lifecycle. To facilitate this, video tutorials on product lifecycle management (PLM) are provided to help students acquire the basic understanding of the principles of product design.

\section{ii. Introduction to Systems Engineering Principles using moderately complex} Electro-Mechanical Systems

Today LEGO Mindstorms are extensively used to teach math, science and engineering to high school students and their success is very well documented ${ }^{7,8,9}$. In this paper, LEGO Mindstorms robot is used as an example system to describe the prize challenge. LEGO Mindstorms robots can be considered moderately complex Electro-mechanical systems which allow students to use servo motors and computer processor to operate robot assembled using standard components known as 'LEGO bricks' which are included in the kit. Tutorials guides ${ }^{10,11}$ are used to teach students how to build a robot using the LEGO Mindstorms kit. The kit also includes the programming software 'NXT-G'. This software allows users to create programs which can be uploaded to the computer of the robot so that it can perform various tasks. Tutorial guides ${ }^{12,13}$ are provided to familiarize students with NXT-G programming. 


\section{iii. Computer Aided Design using Dassault Systemes CATIA V6}

Dassault Systemes (DS) CATIA V6 is used in this curriculum as the CAD software of choice. Curriculum developers have built a component library of LEGO bricks so that students can assemble and visualize any robot inside a V6 environment, just as they would do with other physical components. Also, a number of customized workbenches were built and added to the software which made assembly of the custom parts with original LEGO bricks very easy by providing users added functionality to create standard LEGO connectors on the custom parts. Tutorials were developed to provide students an understanding of the basic principles of CAD, sketching, part design, assembly and usage of customized workbenches inside CATIA V6.

iv. Additive manufacturing using 3D printers

To print a part using a 3D printing machine, it is necessary to generate a corresponding STL file. STL files represent a standardized data format that is universally recognized by all 3D printing machines. Once an STL file is generated, it can be uploaded to the 3D printer via a software interface to set up the print job and calculate build time, which is stipulated as an important criterion in prize challenge to measure design efficiency from manufacturing perspective. Once a component is printed, the students need to finish the part by cleaning and sanding it before it can be assembled. So in order to learn how to perform all these tasks, various tutorials were developed.

\section{v. Collaboration Tools}

The prize challenge is developed to accommodate students participating from multiple locations concurrently. In such a setting, it is extremely important to provide students with an IT infrastructure that fosters and enhances the collaboration between the various team members. In order to encourage collaboration, Dassault Systemes have developed an online social network called SwYm (ㅌee What $\underline{\text { You }}$ Mean) ${ }^{14}$ which provides a necessary platform for DS product users. Detailed description of the components of SwYm is provided in the next section. Along with SwYm, the serverbased DS V6 environment allows users to save user data on a central server that can be accessed by other users with appropriate access privileges from any geographical location. Tutorials were developed to introduce students to take advantage of these collaborative tools during the prize challenge.

\section{Integrated Design and Manufacturing Infrastructure (IDMI)}

Our Integrated Design and Manufacturing infrastructure is based on the Cloud-based Design and Manufacturing (CBDM) paradigm, which is defined as a product development model that enables collective open innovation and rapid product development with minimum costs through social networking and crowd-sourcing platforms coupled with shared service pools of design, manufacturing resources and components. This paradigm has already been used at Georgia Tech to teach graduate level courses ${ }^{15}$ and its IT components have been discussed in detail by Rosen et al. ${ }^{16}$. 


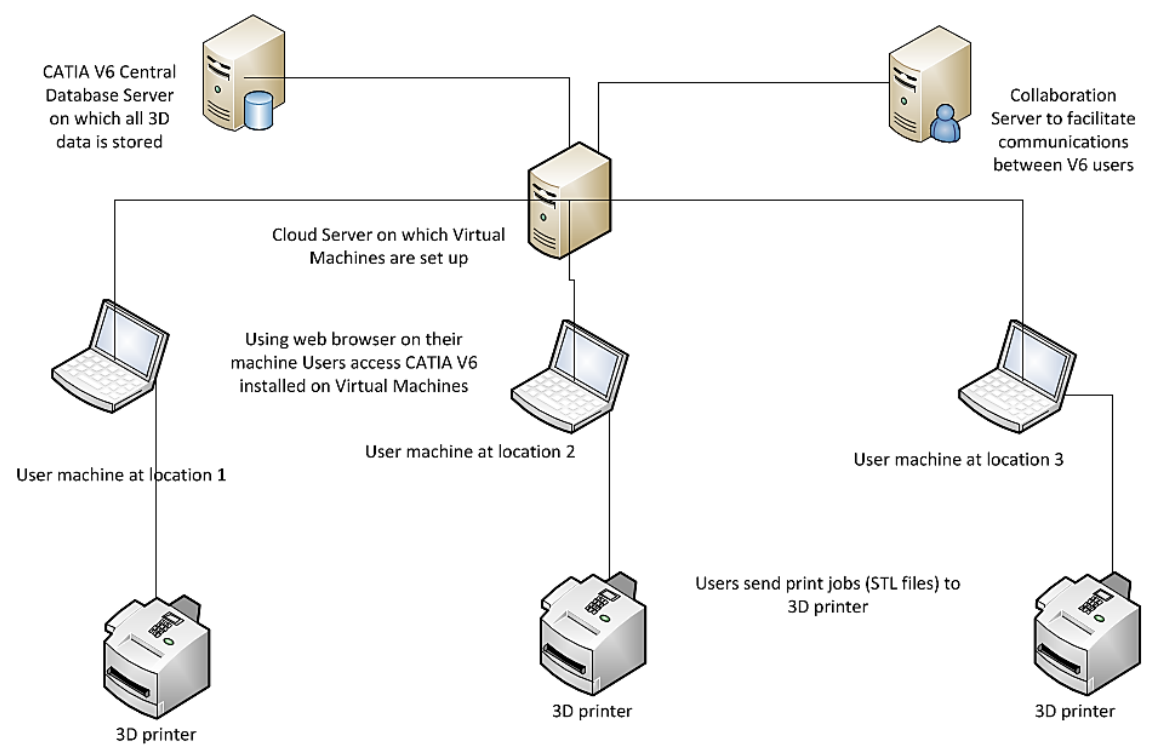

Figure 1: Integrated Design and Manufacturing Infrastructure

As shown in figure 1, the Integrated Design \& Manufacturing (IDMI) infrastructure is utilized to deliver the curriculum as well as to run the prize challenges from multiple locations concurrently. The Dassault Systems V6 environment uses a database server which acts as a central location on which all 3D data is stored. Also, V6 requires a collaboration server for users to communicate while using the software. CATIA V6 is installed on virtual machines on a cloudbased CITRIX server which uses Microsoft Terminal Services software to deliver Windows applications like CATIA V6 to PCs, Apple Macintosh computers, X terminals and UNIX workstations. User-machines using these operating systems can connect to the virtual machines through their web browser by providing their credentials on the web interface, as shown in figure 2 .

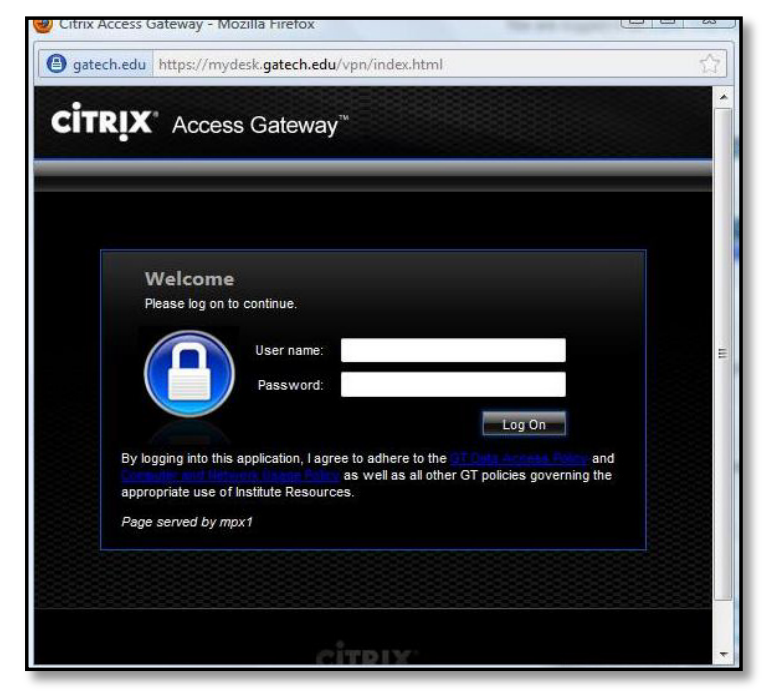

Figure 2: Citrix access gateway/user interface 
Since CATIA V6 is a graphically intensive application, users with relatively less sophisticated computing workstation and broadband internet connection would still be able to access it using CITRIX virtual machines. Figure 3 shows user working on LEGO wind turbine blade model in CATIA V6 using the virtual machine accessed through CITRIX server.

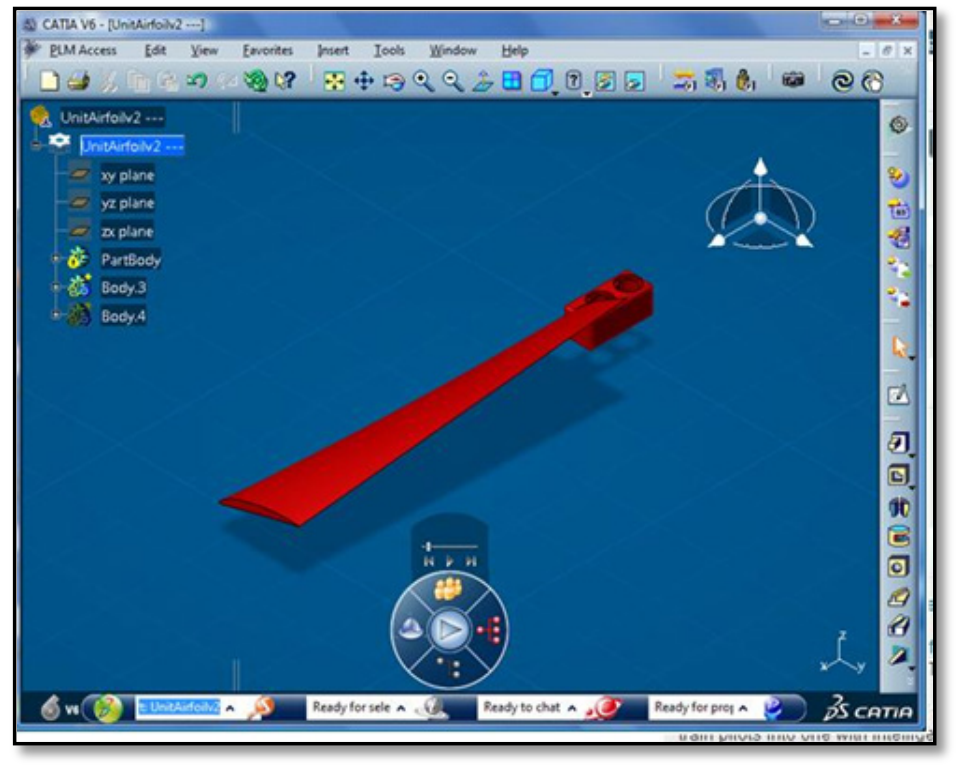

Figure 3: CATIA V6 running on a virtual machine hosted on CITRIX server

As shown in figure 1, users from multiple locations can access the software, create 3D models, store them on the central server and print the parts using 3D printers. This infrastructure can be used in various ways to deliver the pedagogical model. High schools can build a capstone course with prize challenge as a final project. Students can access the software through virtual machines from any location. Also students from multiple high schools can participate in such project. Another way to implement this model is through a summer camp which can be organized for high school students to participate in such challenge during the summer-break. In next section, our implementation of the pedagogical model in one such summer camp, which was conducted at two geographically distant locations concurrently, will be discussed. In addition, a Grand Challenge can be introduced which can involve high school students nationwide. In such a challenge, students can study the curriculum as an extra-curricular activity. High school clusters can be set up nationwide, which would function as manufacturing hubs hosting $3 \mathrm{D}$ printers. The inherent scalability of our IDMI infrastructure allows for accommodating any of these configurations.

\section{SwYm Online Community}

In an ideal CBDM-based paradigm, a Central Interfacing Server (CIS) would also provide collaboration tools. However, as discussed earlier, in our implementation we used Dassault Systems online social networking environment SwYm as the main platform for collaboration. There are two main reasons for choosing SwYm:

i. SwYm already has a large pool of DS V6 users who can accelerate the learning process of new students by providing guidance and support at each step. 
ii. SwYm provides a rich tool-set for collaboration, which is a key component for successful implementation of the pedagogical model.

Since SwYm is a community for existing DS users, ranging from professionals to high school students, it is necessary to group new users in an appropriate community, according to their level of expertise. Hence, a separate community was setup on SwYm for students participating in the program.

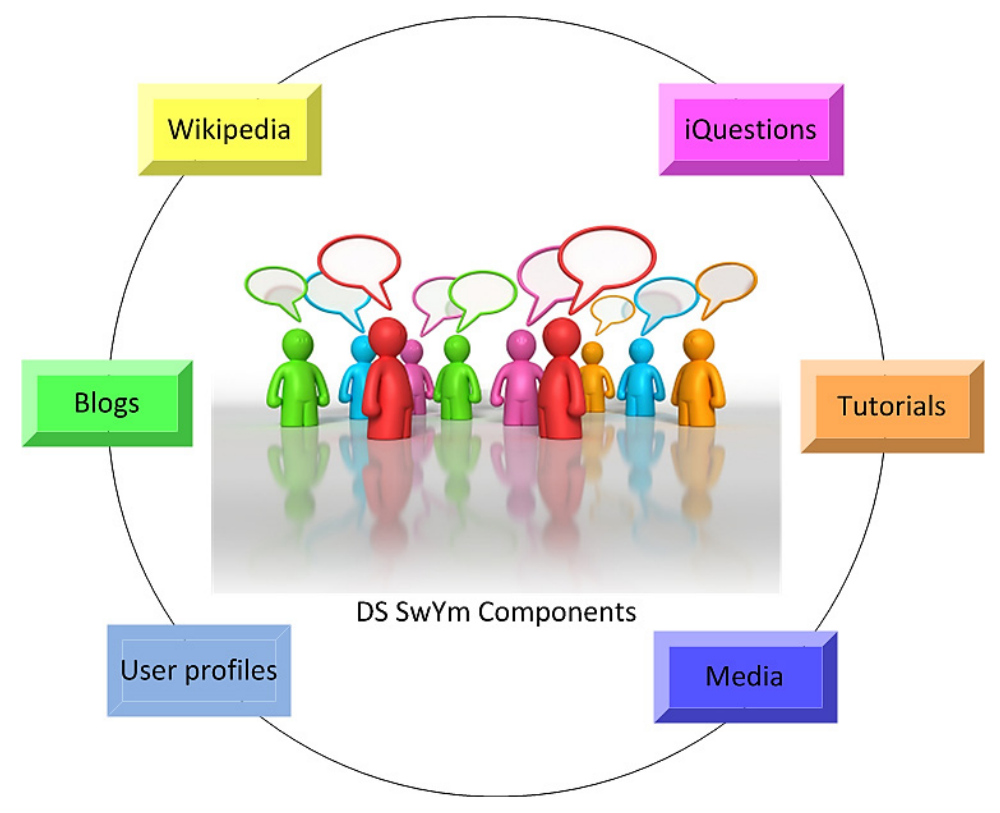

Figure 4: DS SwYm Components

Figure 4 depicts the collaborative components or tools available to users of a SwYm community. Once students get access to the community, they can create their own profiles and add team members to their network. Students can also upload media files like videos or pictures of their virtual or physical models as well as 3DXML files, a proprietary 3D file format developed by Dassault Systemes, for real-time visualization of the 3D models generated using V6. Mentors and students can post their ideas using blogs and follow their team's daily progress by creating a common team blog page. Challenge moderators can create an official challenge blog page where they can post challenge rules and daily updates. At the end of the challenge, teams are asked to officially document their work using Wikipedia. iQuestions is a forum where users can post their questions and any community member can post replies. In following section examples of each of these components will be given to show how they were used during a summer camp (Appendix C).

\section{Transportability of the pedagogical model}

Since 3D printers use the STL format, which is recognized by all commercial and most of the open source CAD software applications, this pedagogical model can be applied to virtually any CAD system, not just CATIA V6. In case alternative CAD software packages are used, , any third-party cloud-storage space (e.g., Dropbox, etc.) could be used to share CAD and project data with other users. As explained in section 1, an ability to build a virtual LEGO robot inside 
CATIA V6 is one of the essential requirements for successful implementation of our model. In order to accomplish this capability, curriculum developers have built a component library of LEGO Mindstorms bricks so that students can assemble and visualize any Mindstorms robot inside a V6 environment. Similar component library would need to be created for 3rd party CAD software. If Citrix Server-based virtual machines are not available, services from any virtual machine provider can be rendered for the program duration at an additional cost, which can be countered by reduction in initial equipment cost, as virtual machines can be run on practically any workstation with average configuration. As mentioned earlier, SwYm can be replaced by any open source Learning Management System, for example Moodle-based web portals ${ }^{17,18}$, to provide an e-learning platform for team collaboration and learning.

\section{A demonstration of the pedagogical model in action}

In summer 2012, the Engineering Design and Manufacturing Summer Camp was conducted concurrently at two geographic locations - Georgia institute of Technology (GT) and the University of Detroit - Mercy (UDM). High school students from multiple states within the U.S. participated in this distributed camp and included a total of 58 students and 13 teachers. Of those participants, 41 students and 10 teachers were located at Georgia Tech. Figure 5 shows the geographical origin of the participants.

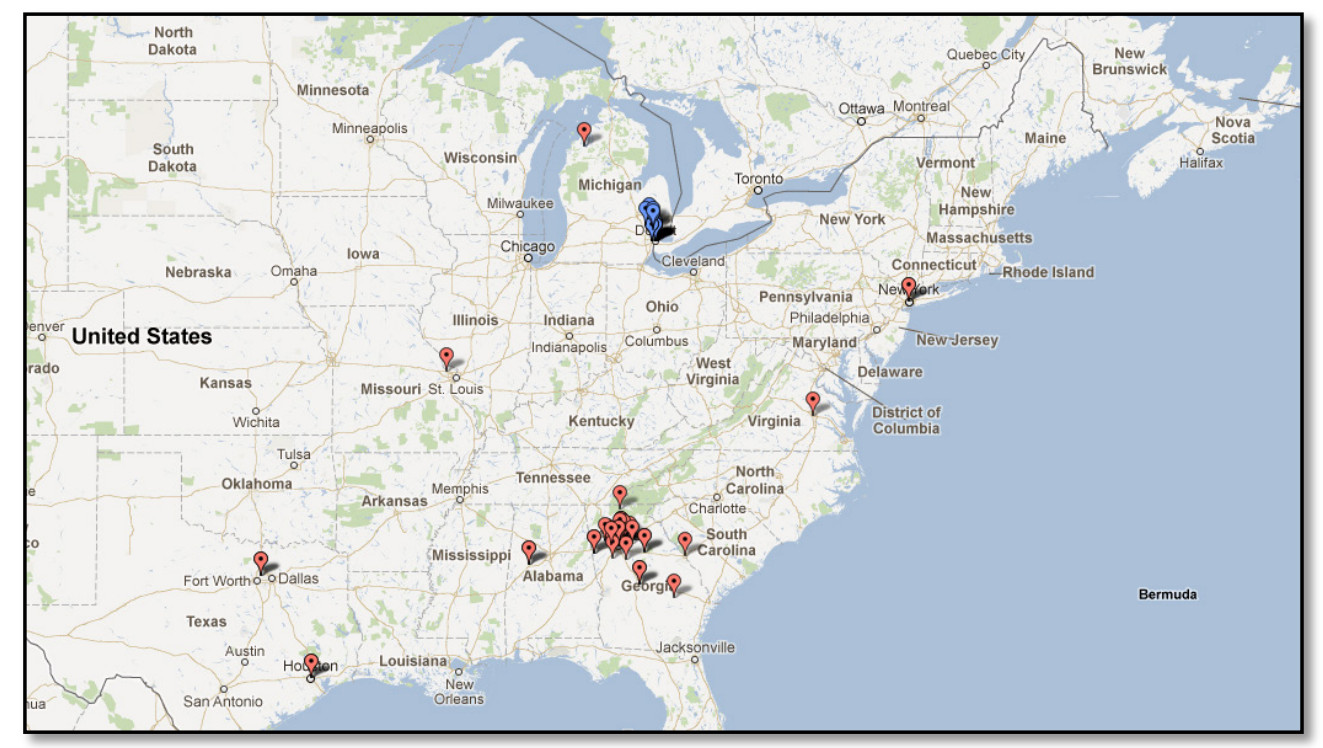

Figure 5: Geographical origin of students in two camps. Red balloons indicate students hosted at Georgia Tech and blue balloons indicate students hosted at UDM, courtesy Google Maps.

The camp was held over the course of two weeks. In the first week, and under the guidance of instructors, students were familiarized with each of the five modules of the curriculum. On the last day of the first week students were given a mini-challenge to practice their newly acquired $\mathrm{CAD}$ and $3 \mathrm{D}$ printing skills. In this mini-challenge, they were asked to generate a 3D model of their choice in CATIA V6, which could later be built physically using 3D printers. Once they completed their mini-challenge, they posted pictures and 3DXML files of their designs on 
SwYm blogs. In the second week, students participated in the actual main prize challenge. Each participating team comprised of students from both locations, GT and UDM. The prize challenge is explained in detail in Appendix B.
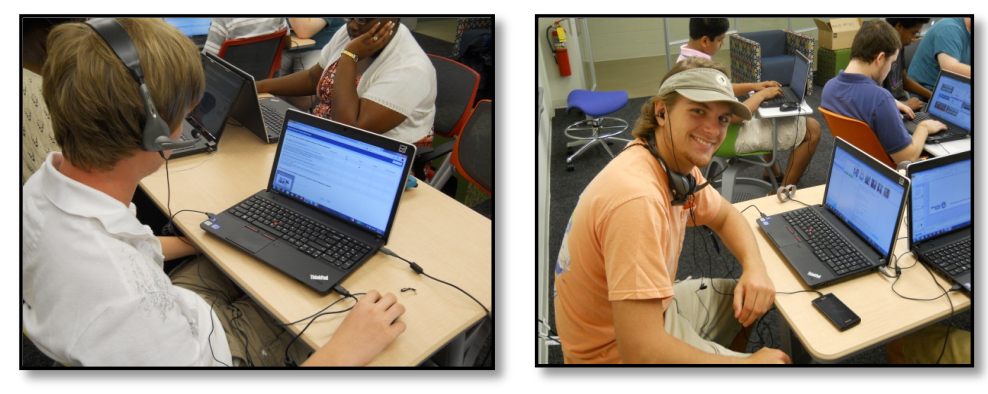

Figure 6: Prize challenge team members collaborating from different locations (Photos printed with permission)

As shown in figure 6, students were provided with a laptop and headphone set to communicate with team members at other geographic locations. High school teachers functioned as teamleaders to mentor the students throughout the challenge. During the second week, the students also learned how to use the collaborative tools mentioned in the previous section. The corresponding tutorials were accessible to the students through the SwYm community page (Appendix C, figures C.1, C.2). Students used the iQuestions forum to post their queries in the community and users with solutions sent replies to those queries (Appendix C, figure C.3). Students were able to post various 3D media to share their creations (Appendix C, figure C.4). During the entire duration of prize challenge team-members blogged extensively to communicate and share ideas with each other (Appendix C, figures C.5, C6). Students documented all their work on team wiki article (Appendix C, figure C.7).

At the end of the second week, students participated in the prize challenge missions and judges evaluated students with respect to their designs and the quality of their collaboration efforts and behavior on SwYm. Based on their comprehensive evaluation, winners were identified.

\section{Formative Assessment}

To evaluate the pedagogical model's success, student surveys were conducted. Of the 41 students who participated at the Georgia Tech site, 30 students responded to the surveys. 28 of the student surveys submitted were $100 \%$ completed. A detailed evaluation report ${ }^{19}$ of this formative assessment exercise including additional teachers' surveys and findings is available from the authors upon request. In what follows, key results of the surveys conducted with students are discussed in order to comment on both the efficiency and the shortcomings of the pedagogical model and our implementation. Potential issues are identified wherever surveys show unsatisfactory outcomes and corresponding solutions are proposed. The student surveys and their results are tabulated in Appendix D.

It was important to understand the efficiency of our curriculum in achieving the desired learning objectives of the pedagogical model. As shown in Table D1 (Appendix D), in general students 
were satisfied with the curriculum. The majority of students (92\%) agreed or strongly agreed that the modules provided were useful for learning the main concepts and that the knowledge gained was sufficient to participate in the prize challenge.

Table D2 shows how students grasped principles of CAD by learning CATIA V6 and how they learned to collaborate on SwYm. Even though the majority of students had no problem learning CATIA V6, approximately $10 \%$ of the students found it somewhat difficult to follow the tutorials. Suggestions were made by the instructors to add more tips and animations in the tutorials to make them more user-friendly. The majority of students (over 90\%) agreed or strongly agreed that they had gained enough proficiency to use the $2 \mathrm{D}$ sketcher inside the CATIA V6. Over 86\% students gave positive response when they were asked if they would be able to generate a 3D model of part of their imagination after following this class.

Table D3 shows how effective individual modules were in developing an understanding of the module specific content. The students gave scores from 1 to 5 , with 5 meaning full understanding and 1 meaning no understanding at all. The responses varied, with the means ranging from 3.69 to 4.10 , which is in the satisfactory range. Considering the very short time of one week to learn the relatively dense material, the high school students grasped enough to implement it in the prize challenge the following week.

The students were asked to rate their satisfaction with the Co-create, Design, Build and Operate components of the program, and then respond to an open-ended component regarding what worked and what did not work well in that respect. Figure 7 shows students' response to how satisfactorily the prize challenge helped them participate in all four components of the model.

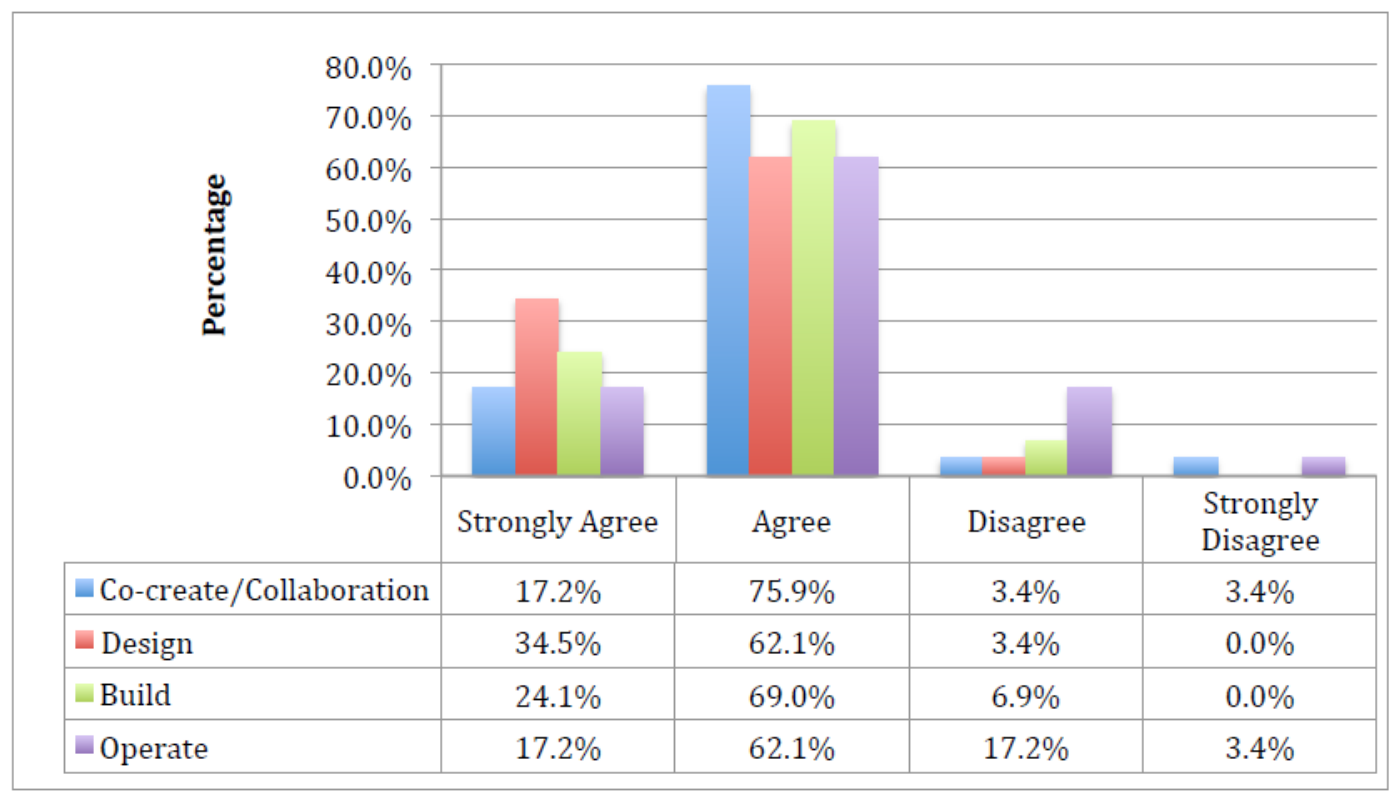

Figure 7: Student satisfaction with the CDBO components of the pedagogical model. 


\section{Co-create/Collaboration}

Since the summer camp required collaboration between team members located at two different locations, it was important to measure how different collaboration tools performed. Students used free video conferencing application like Skype to communicate in real time, while they used SwYm to post their ideas and share their work. The majority of students agreed that they were able to use SwYm successfully as a collaboration platform. However, some students preferred using just real time communication and showed slight apathy towards using social media tools like blogs and Wikipedia, which we believe demonstrates that not all students have had an exposure to social media tools prior to the camp.. Also, we believe that in future a more sophisticated and professional web conferencing application would be more effective for realtime team meetings compared to the free online video-conferencing tools like Skype.

During the second week of the summer camp, students also used virtual meetings tools like Skype to communicate in real-time with the team-members. However, due to personal preferences, some students did not know about the tools chosen by their team-members and this caused some delays and confusion among them. Since SwYm does not offer features for virtual meetings within its web-portal, it was recommended that a common virtual meeting tool is added to the infrastructure and is taught during the first-week of the program in order to familiarize students before they start using it during the prize challenge week.

\section{Design}

The students were very satisfied with the design aspect of the program, with almost all of them responding "satisfied" or "very satisfied", resulting in a mean score of 3.31. The responses to the open-ended part of Question 5 indicate this satisfaction as well. They indicated that CATIA worked well but the virtual machines did not. A few comments also indicated that more time would have been helpful in the design phase.

"I enjoyed being able to design the wheels and claw on the CATIA software. Having all the parts on the virtual machine helped with reviewing the parts of group members and improving design. The only downside was that the CATIA program on the VM got really slow and many times I was disconnected."

"CATIA worked well."

"The program was easy to learn and once I got the hang of it. Easy to use."

"I wish there was more of a design phase, rather than jump in head first."

$\underline{\text { Build }}$

Two 3D printers were used at Georgia Tech to print 3D parts for a total of 10 teams during the second week of the prize challenge. On average each team used approximately 5 hours of 3D printing during the week. However, all print jobs were requested simultaneously by all teams, and so the instructors had to run the 3D printers continuously for 48 hours, which made the print jobs available just on time to participate in competitions. This did not allow students to revise their design in case of unsatisfactory performance. Here are some of the comments from the students about 3D printing: 
"The printing took a really long time."

"3d printers are cool."

"I thought the building was the best part, and the LEGO kits were perfect. The only thing I didn't like was the wait on getting the $3 D$ parts printed."

Therefore, in order to make the printing more manageable, at least three 3D printers must be allotted in future to accommodate printing for 10 teams in such summer camp setting.

\section{Operate}

As explained before, long printing time did not allow some students to do more rigorous testing before participating in the challenge final round and so around $21 \%$ students were dissatisfied with the Operate stage of challenge. Here are student comments:

"We did not have enough time to test out every design."

"I was a little dissatisfied with the $3 D$ printing, mostly because we got the wheels about a half hour before the competition, and therefore had little time to see what worked and what didn't. The NXT kit, however, worked well."

In order to provide more time for students to work on the Build and Operate stages, instructors have proposed a restructured delivery format of the two-week long summer camp. This revised format will introduce students to prize challenge on the first day of the camp instead of the beginning of the second week. The students will go through the necessary CATIA tutorials within the first 3 days of the camp. This restructuring will allow them to spend more time on building their robot and generating customized 3D models, which in turn should provide more time for 3D printing (Build) and testing (Operate) activities.

As mentioned in objective a) in section 1, it was necessary to provide high school students an experience of Engineering as a unified profession. As shown on Table D4, after attending this program, more than $90 \%$ participants developed a more thorough understanding of what Engineers do. Along with understanding, it was important to measure if positive attitude towards Engineering was developed using the pedagogical model. Table D4 shows that majority of students $(90 \%)$ expressed their desire to learn more about engineering design and manufacturing in the future. As shown on Table D5, students were asked if this summer camp was able to develop a better aptitude towards Engineering and as shown large majority agreeing that it did help them learn more about engineering and they found engineering interesting and worth learning.

Table D6 shows most students agreed that they would like to pursue a profession which gives opportunity to design, invent, or develop new products or tools. Overall, the pedagogical model has been quite satisfactory in fulfilling all the six objectives mentioned earlier. 


\section{Summary and closing remarks}

A prize-challenge based pedagogical model was introduced. Integrated Design and Manufacturing Infrastructure (IDMI) was described to deliver this model and it was shown that using IDMI the pedagogical model can be delivered nationwide in different settings, for example as capstone course in high schools or as a summer camp or as a semester or a year-long grand challenge in which students compete nationally. Also, portability of this model was discussed in detail to demonstrate the flexibility available while applying it to various CAD software and infrastructure setups. A case-study of this model was presented in which this model was applied to a two-week geographically distributed collaborative summer camps. Extensive formative assessment activities were performed and analyzed. Lessons were learned in what worked well and suggestions were made on what can be improved in the future. Overall survey results show a very successful implementation of this model with a considerable success in motivating high school students to pursue careers in Engineering. In summer 2013, we plan to scale the summer camps to additional three locations. This will provide an opportunity to test the revised delivery structure as discussed in section 3. Special emphasize will be put on improving collaboration between team-members. Also, an additional prize challenge in form of a blade redesign for a remotely controlled helicopter will be introduced in addition to the current wind turbine and ground robot prize challenges implemented in 2012 summer camps.

\section{Acknowledgements}

This research was performed as part of Manufacturing Experimentation and Outreach (MENTOR) program funded by Defense Advanced Research Projects Agency (DARPA). The formative assessment was conducted by Center for Education Integrating Science, Mathematics and Computing (CEISMC) Evaluation Group at Georgia Tech.

\section{References}

1. Members of the 2005 "Rising Above the Gathering Storm" Committee, National Academy of Sciences, National Academy of Engineering, Institute of Medicine (2007): Rising Above the Gathering Storm: Energizing and Employing America for a Brighter Economic Future. National Academies Press. 2007, ISBN 0309187583.

2. The white house press release (2009): "President Obama Launches Educate to Innovate Campaign for Excellence in Science, Technology, Engineering and Mathematics (STEM) Education", http://www.whitehouse.gov/the-press-office/president-obama-launches-educate-innovate-campaignexcellence-science-technology-en , Nov 2009. URL retrieved on 4/5/2012

3. The white house press release (2012), "President Obama Announces New Plan to Create STEM Master Teaching Corps", http://www.whitehouse.gov/blog/2012/07/18/president-obama-announces-new-plancreate-stem-master-teaching-corps, July 2012. URL retrieved on 4/5/2012

4. Committee on Understanding and Improving K-12 Engineering Education in the United States, National Research Council (2009): Engineering in K-12 Education: Understanding the Status and Improving the Prospects. National Academies Press. 2009, ISBN 0309137780.

5. Crawley, E. Malmquist, J., Ostlund, S, Brodeur. D. (2007): Rethinking Engineering Education: The CDIO Approach. Springer, $1^{\text {st }}$ ed. 2007, ISBN 1441942602. 
6. Wiggins G., McTighe J. (2005): Understanding by Design, Pearson, $2^{\text {nd }}$ edition 2005, ISBN 0131950843.

7. Ranganathan, P., Schultz R., Mardani M. (2008): "Use of LEGO NXT Mindstorms brick in engineering education", Proceedings of the 2008 ASEE North Midwest Sectional Conference 2008. Tulsa, Oklahoma September 17-19, 2008

8. Barker, B., Ansorge, J. (2007): "Robotics as means to increase achievement scores in an informal learning environment", Journal of Research on Technology in Education, 2007 39(3), 229.

9. Whitman, L, Witherspoon, T. (2003): “Using LEGOs to interest high school students and improve K12 stem education". Proceedings of the $33^{\text {rd }}$ Frontiers in Education 2003. Westminster, Colorado, November 5-8, 2003

10. Valk L. (2010): The LEGO MINDSTORMS NXT 2.0 Discovery Book: A Beginner's Guide to Building and Programming Robots, No Starch Press, 1st ed. 2019, ISBN 1593272111.

11. Perdue D., Walk L. (2010): The Unofficial LEGO MINDSTORMS NXT 2.0 Inventor's Guide, No Starch Press, 2nd ed. 2010, ISBN 159327215.

12. Griffin T. (2010): The Art of LEGO MINDSTORMS NXT-G Programming, No Starch Press, 1st ed. 2010, ISBN 1593272189.

13. Kelly J. (2010): LEGO MINDSTORMS NXT-G Programming Guide (Technology in Action), Apress, 2nd ed. 2010, ISBN 1430229764.

14. Dassault Systemes SwYm Web Portal: https://iam.3ds.com/service/social/, URL retrieved on 4/5/2012

15. Schaefer D., Thames L., Wellman R., Wu D., Rosen D. (2012): "Distributed Collaborative Design and Manufacture in the cloud - motivation, infrastructure and education", Computers in Education Journal 2012, AC 2012-3017.

16. Rosen D., Schaefer, D., and Schrage D. (2012): "GT MENTOR: A High School Education Program in Systems Engineering and Additive Manufacturing" Proceedings of the 23rd Annual International Solid Freeform Fabrication Symposium - An Additive Manufacturing Symposium (SFF 2012). Austin, Texas, August 6-8, 2012.

17. Cole J., Foster, H., Using Moodle (2007): Teaching with the Popular Open Source Course Management System, O'Reilly Media; $2^{\text {nd }}$ ed., ISBN 059652918X.

18. Dougiamas, M., Taylor, P. (2003): Moodle: Using learning communities to create an open source course management system. In World conference on educational multimedia, hypermedia and telecommunications (Vol. 2003, No. 1, pp. 171-178).

19. Center for Education Integrating Science, Mathematics and Computing (CEISMC) Evaluation Group, Georgia Tech (2012): Manufacturing Experimentation and Outreach (MENTOR) Program Summer Camp July 9 - July 20, 2012 Evaluation Report, August 2012. 
First year

- Second year

$\square$ Third Year

Key Words:

\section{Enduring Understandings addressed}

- Product lifecycle

- Manufacturing process

- Collaboration tools

$\square$ Design tools

- Project management

Materials concepts

G Globalization

- Decision support tools

- Systems Engineering and development

$\square$ Other

\section{Standards Addressed}




\section{Curricular Context}

1.

2.

3.

4.

5.

\section{Goals:}

1.

2.

3.

4.

5.

What key knowledge and understandings are desired?

Students will know and understand that...

1.

2.

3.

4.

5.

\section{What key skills will students acquire as a result?}

Students will be able to...

1.

2.

3.

4.

5. 


\section{Plan Learning Experiences}

What sequence of teaching and learning experiences will equip students to engage with, develop, and demonstrate the desired understandings? 


\section{Appendix B : Prize challenge description of Engineering Design and Manufacturing Summer Camp 2012}

Following were the guidelines for Ground Vehicle Prize Challenge:

- As shown in figure B.1, a playfield was prepared for the prize challenge. So called tritium samples (in circular area at top left corner and a plastic bin(in rectangle area at the top right corner) were placed on the field. The playfield had three different types of terrain constructed using foam(blue), bumpers(stripes) and beads(red). Black area is the docking area where robot would be placed before the mission begins. Green area contains a flag, that robot is required to pick up and place near the circular area of tritium samples.

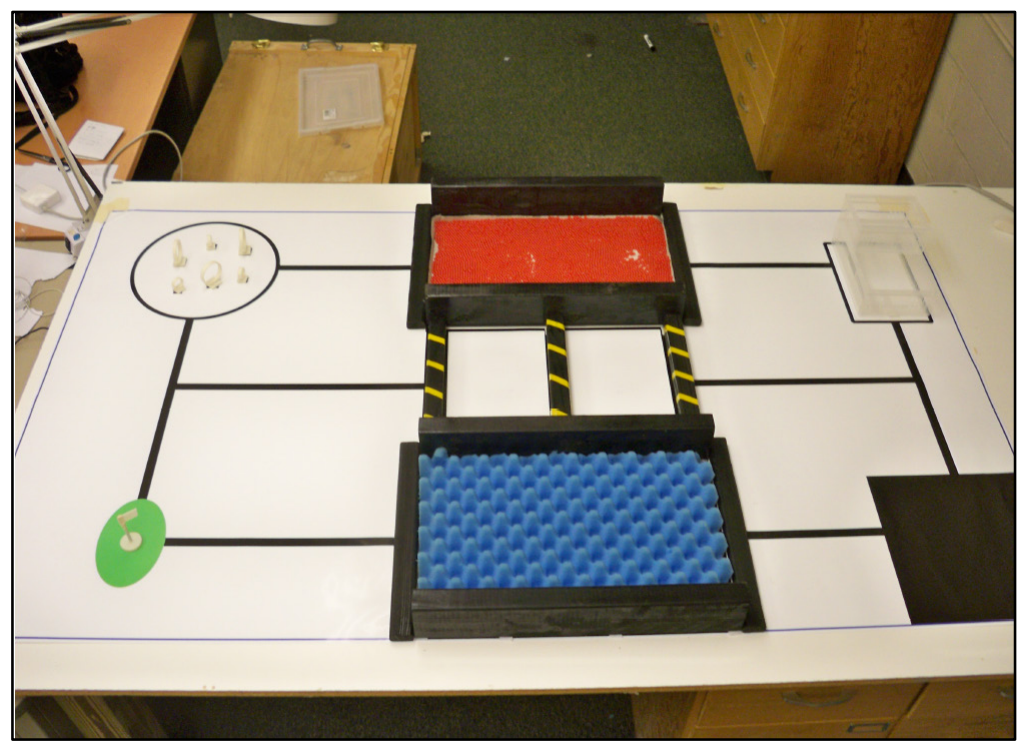

Figure B.1: Prize Challenge playfield

- Students were asked to build a new robot using the LEGO Mindstorms kit. An example of LEGO Mindstorms robot is shown in figure B.2.

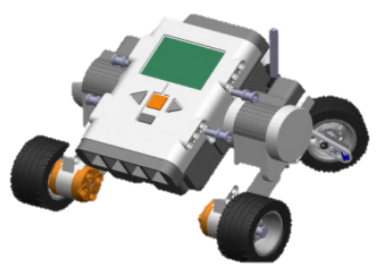

Figure B.2 A 3D model of example LEGO robot 
- Once the basic robot was built, students were required to model and print custom wheels and robotic arm so that they could attach those parts to the robot which would enable robot to perform various missions like picking up sample parts lying on the playfield and dropping them in the bin. Teams earned more points if robot was able to traverse through more than one type of terrain before dropping the samples in the bin. This required students to be innovative with the wheel design. The collector bin had two levels, which required the robotic arm to be flexible enough to reach at both levels.

- Students were also required to write a computer program which they uploaded on the NXT computer of the robot so that the robot could perform various missions as required by the prize challenge.

- Using CATIA V6, Students developed 3D model of custom parts and assembled them virtually inside CATIA V6 to verify manufacturing feasibility and operation of the parts. Students wrote the program in NXT-G software which allowed robot to perform various missions required in the challenge. Figure B.3 shows 3D models of custom wheels and arms designed my students.

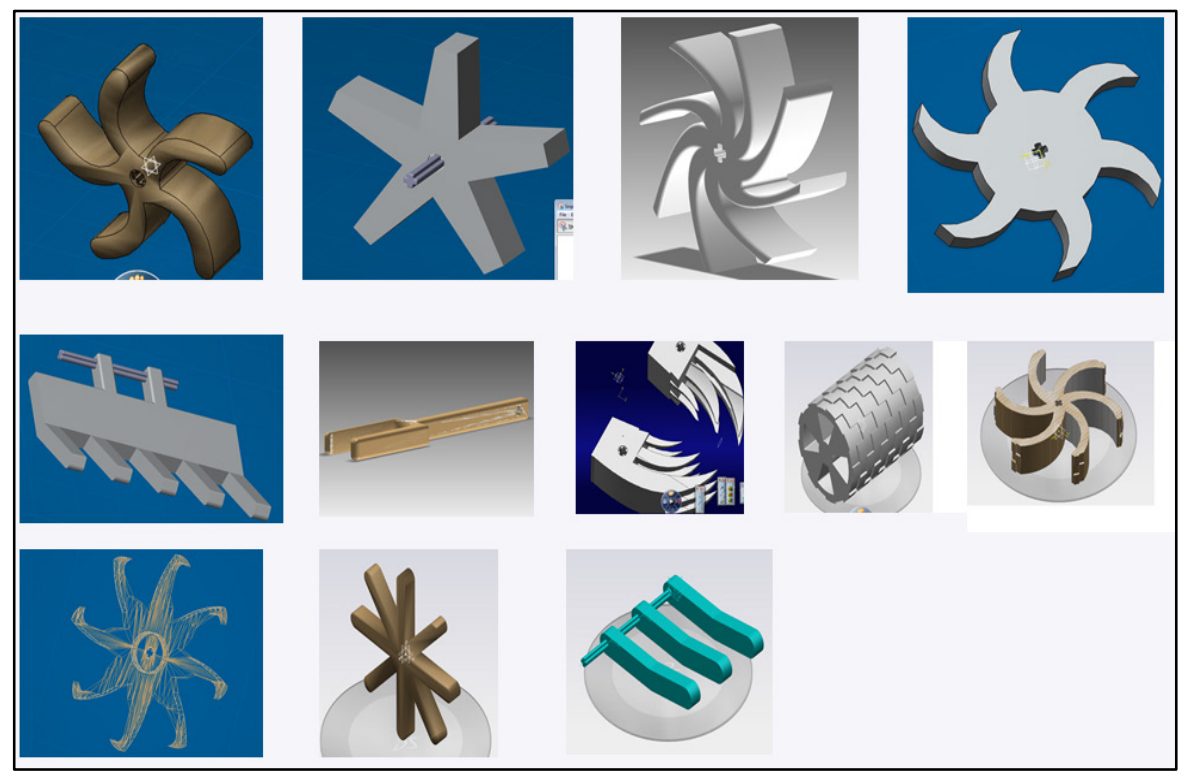

Figure B.3 Custom parts designed by student teams in CATIA V6

- Once 3D modeling was completed, students built the custom parts using 3D printers. After performing finishing operations on the printed parts, those parts were assembled to the robot and then robot was tested for its mission performance. Figure B.4 shows custom parts assembled to the robots and some robots performing the challenge missions. 


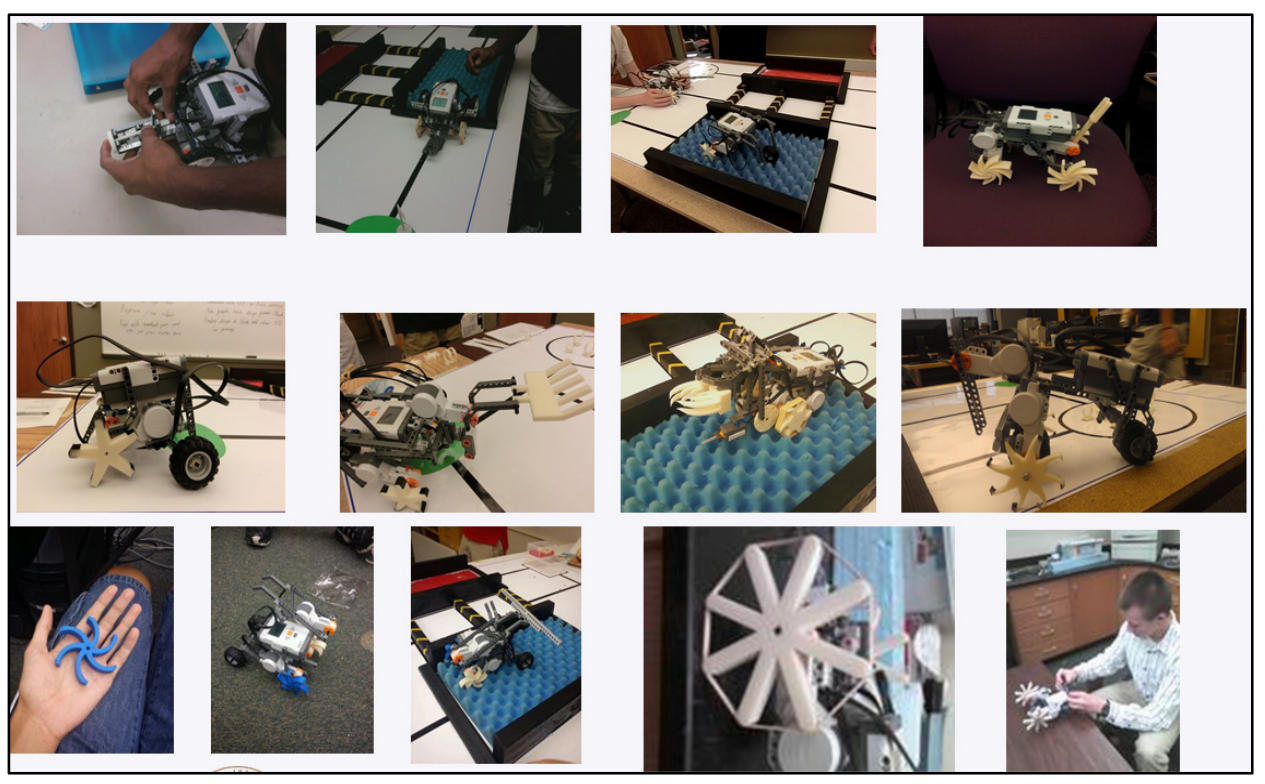

Figure B.4 Robots with custom parts assembled 


\section{Appendix C: Collaboration through SwYm during Engineering Design and Manufacturing Summer Camp 2012}

In this appendix, various examples of SwYm components used during the prize challenge are given.

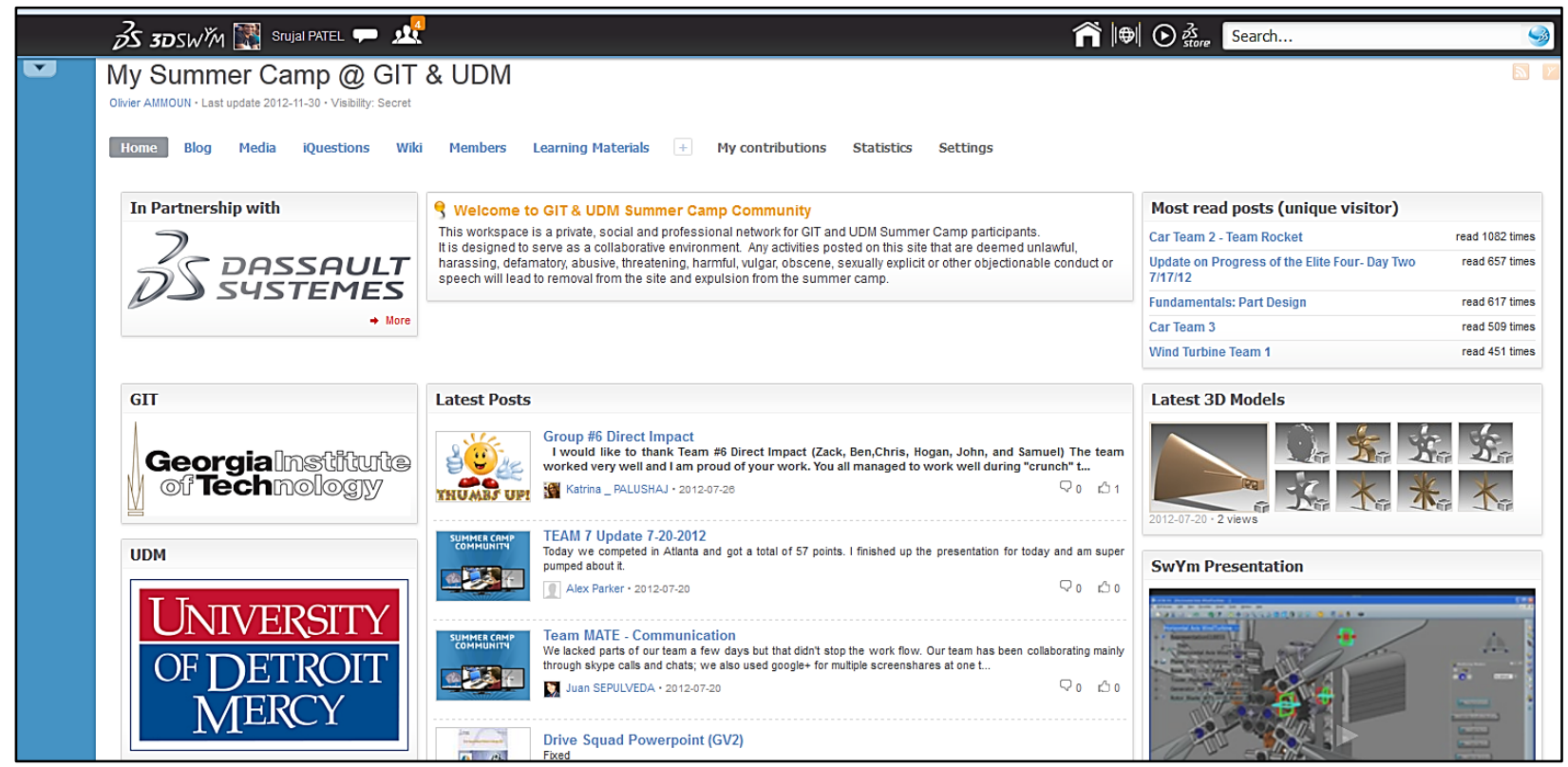

Figure C.1: Summer Camp Community page on SwYm Website 


\section{Appendix C}

\section{Summer Camp

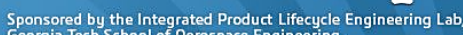

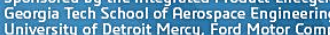

\section{DS ACADEMY}

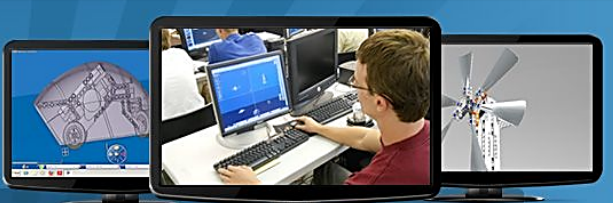

Aิ > My Summer Camp @ GIT \& UDM > Learning Materia

My Summer Camp @ GIT \& UDM

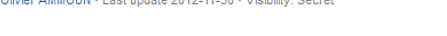

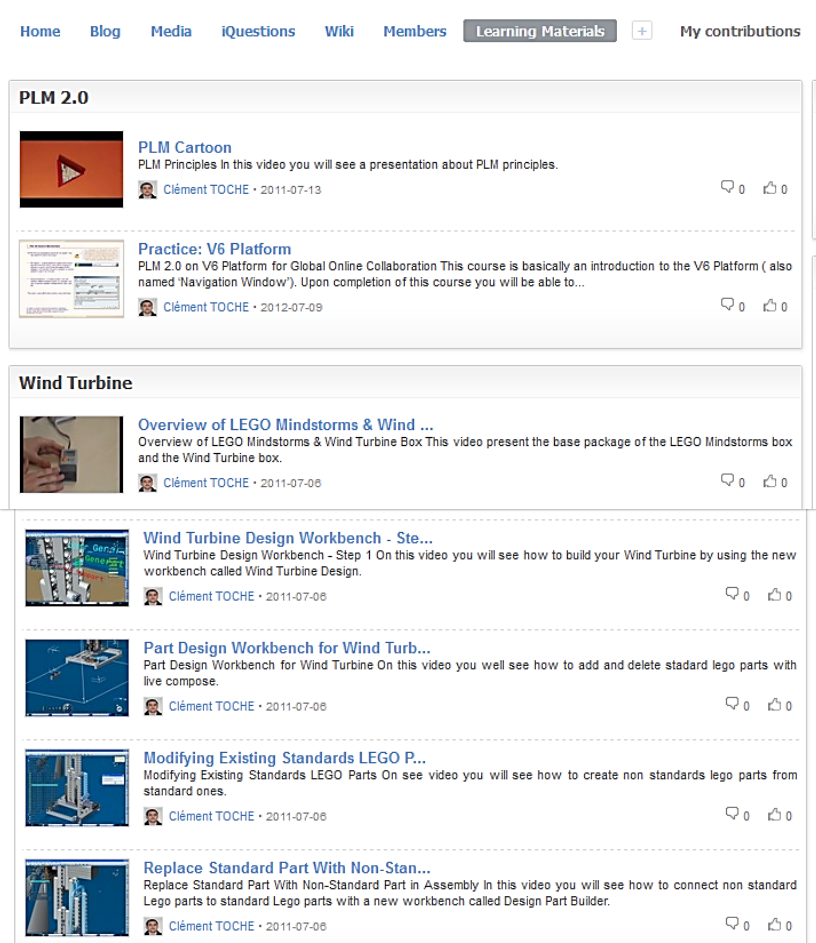

Manufacturing

จ० מo

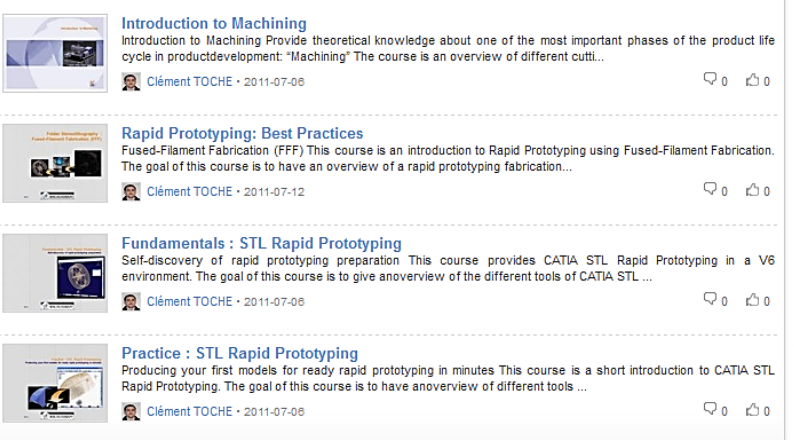

Collaboration

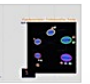

Fundamentals: Collaborative Tools

Self-discovery of collaborative design practices Fundamentals: Collaborative tools on V6 This course provide 8. Clèment TOCHE. $2012-07 \cdot 11$

Q० B०

\section{Design}

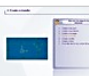

Fundamentals: Sketcher

Self-discovery of rapid profile creation Upon completion of this course you will be able to: Understand the basics of

\& clément TOCHE $\cdot 2012-07-09$

Fundamentals: Part Design

Self-discovery of $3 D$ Mechanical part design Easy creation and easy modifications, this is what CATA solid modeler
inmediately provides to your students \& Clèment TOCHE $\cdot 2012-07-13$

Fundamentals: Imagine \& Shape
Self-discovery of treehand shape modeling This course provides CATL Imagine \& Shape knowledge in a V6

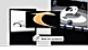
The goal this course is to givean overview of different tools of CATA I Imagine \&

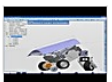

Basic Imagine and Shape : Immersive way.

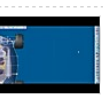
Clément TOCHE $\cdot 2011-07-13$

Advanced Imagine and Shape:Immess...

. \& Clèment TOCHE $\cdot 2011-07-13$

Practice: Photo Studio
Creating your first photo realistic renderings in minutes This course is a short introduction to the Photo Stud
woth \& Clément TOCHE $\cdot 2011-07-00$

\section{Systems Engineering}

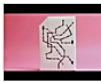

Systems Cartoon

\&. Clément TOCHE $\cdot 2011-07-13$

Lift Experience Systems Engineering with RFLP This video present you CATA Systems workbench to design the logic of your 30 Design.

8. Clement TOCHE. 2012-04-11

_- Introduction to Systems Engineering

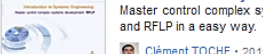

A Clément TOCHE $\cdot 2011-07.08$

Figure C.2: Tutorials on SwYm Summer Camp community 


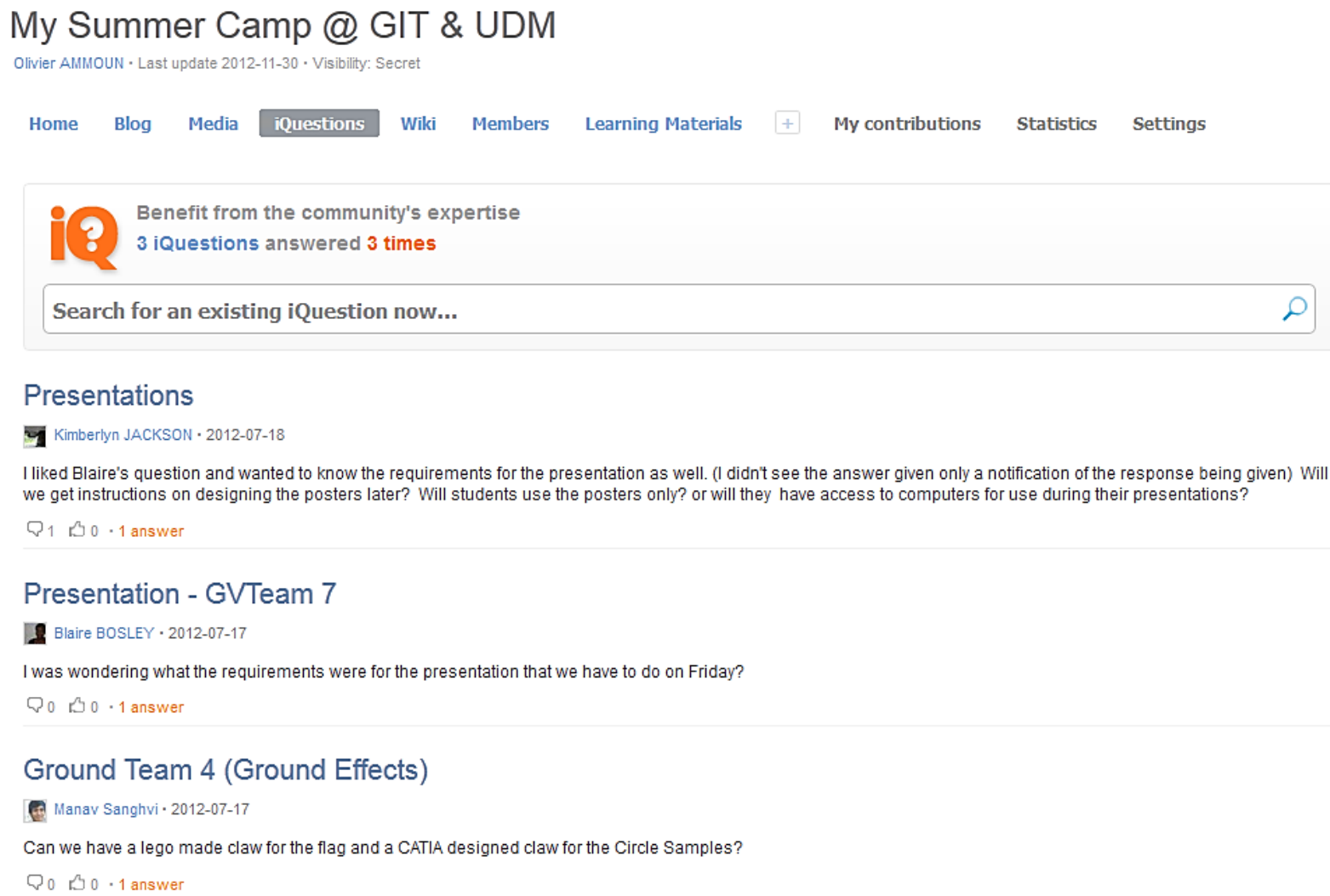

Presentations

4 Kimberlyn JACKSON $\cdot 2012-07-18$

I liked Blaire's question and wanted to know the requirements for the presentation as well. (I didn't see the answer given only a notification of the response being given) Will we get instructions on designing the posters later? Will students use the posters only? or will they have access to computers for use during their presentations?

จ $0 \cdot 1$ answer

\section{Presentation - GVTeam 7}

A Blaire BOSLEY $\cdot 2012-07-17$

I was wondering what the requirements were for the presentation that we have to do on Friday?

Q० @0 $\cdot 1$ answer

Ground Team 4 (Ground Effects)

(2.) Manav Sanghvi $\cdot 2012-07-17$

Can we have a lego made claw for the flag and a CATIA designed claw for the Circle Samples?

๑० $0 \cdot 1$ answer

Figure C.3: iQuestions: User Forum on summer camp community page on SwYm

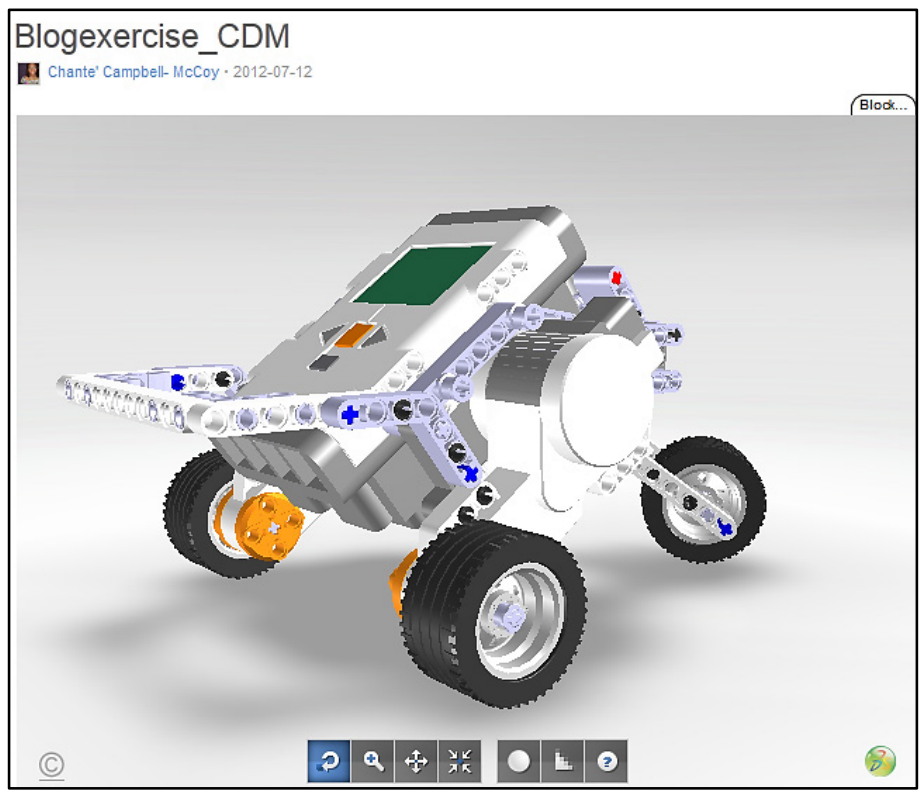

Figure C.4: 3DXML media uploaded on SwYm for realistic visualization of 3D parts and products 


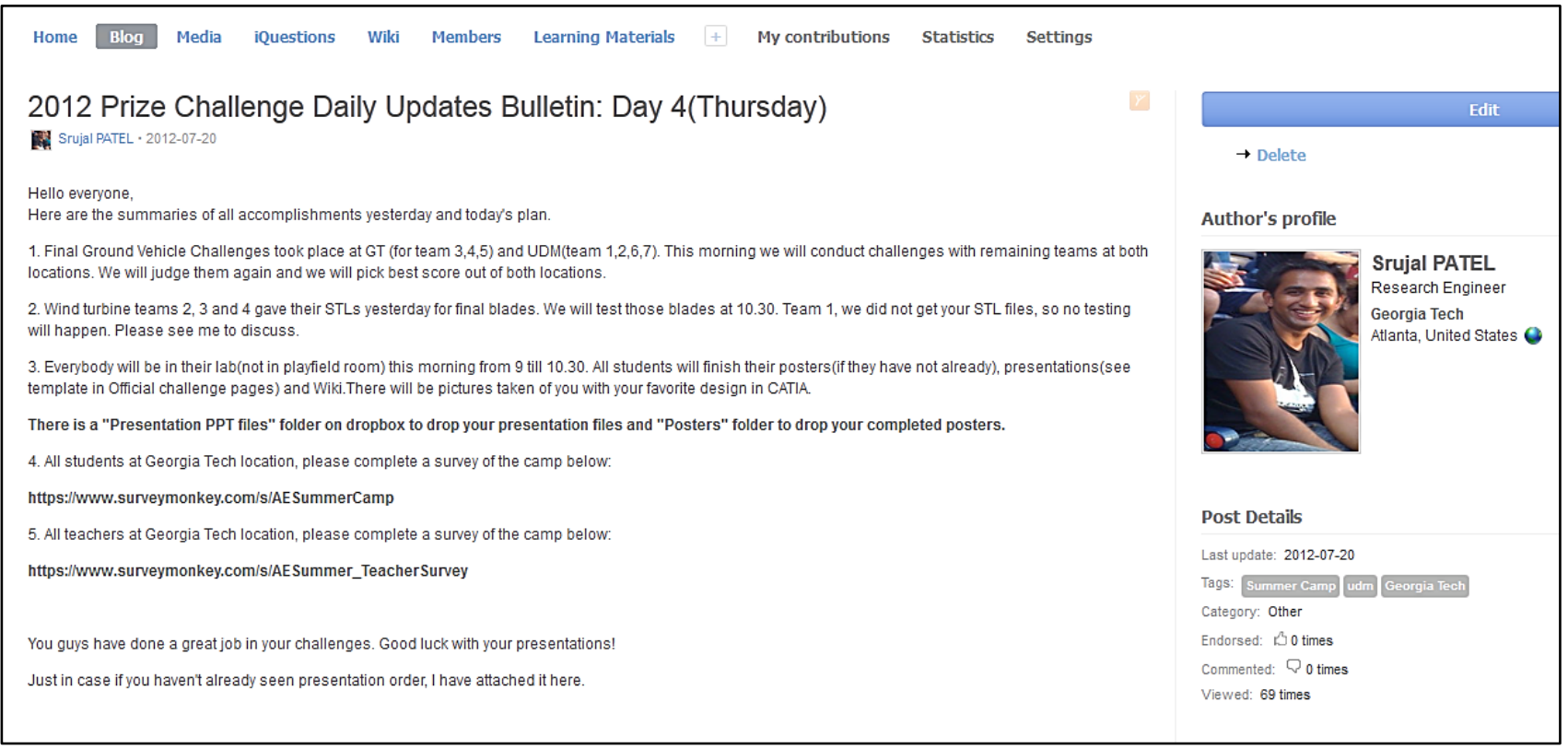

Figure C.5: Instructors using blogs during the challenge

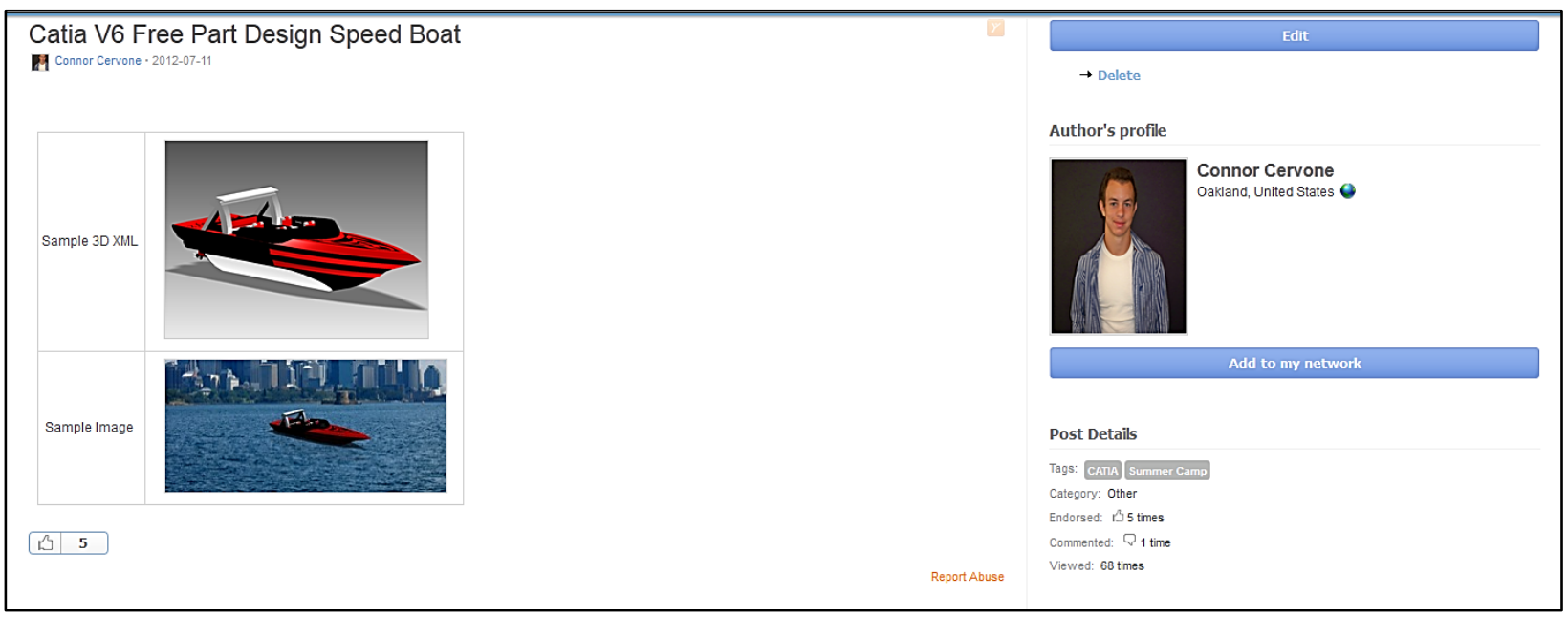

Figure C.6: Student sharing his min-challenge model on the blog (Photos printed with permission) 


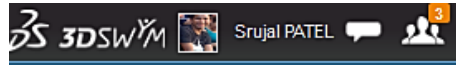

$\uparrow>$ Wiki

\section{ny Summer Camp @ GIT \& UDM}

Jivier AMMOUN - Last update 2012-11-30 - Visibility: Secret

Home Blog Media iQuestions Wiki Members Learning Materials + Mycontributions Statistics Settings

Ground Vehicle Challenge - Loser Domination

Introduction

We are Ground Vehicle Team 1, Loser Domination, of the Ground Vehicle 2012 challenge. This is a collaboration between GT and UDM. We have one week to design and build an autonomous robot out of Lego Mindstorms and parts that we have designed in Catia and printed out. The robot must traverse rough terrain, place a flag, and retrieve tritium "ore" within three minutes in order to gain as many points as possible.

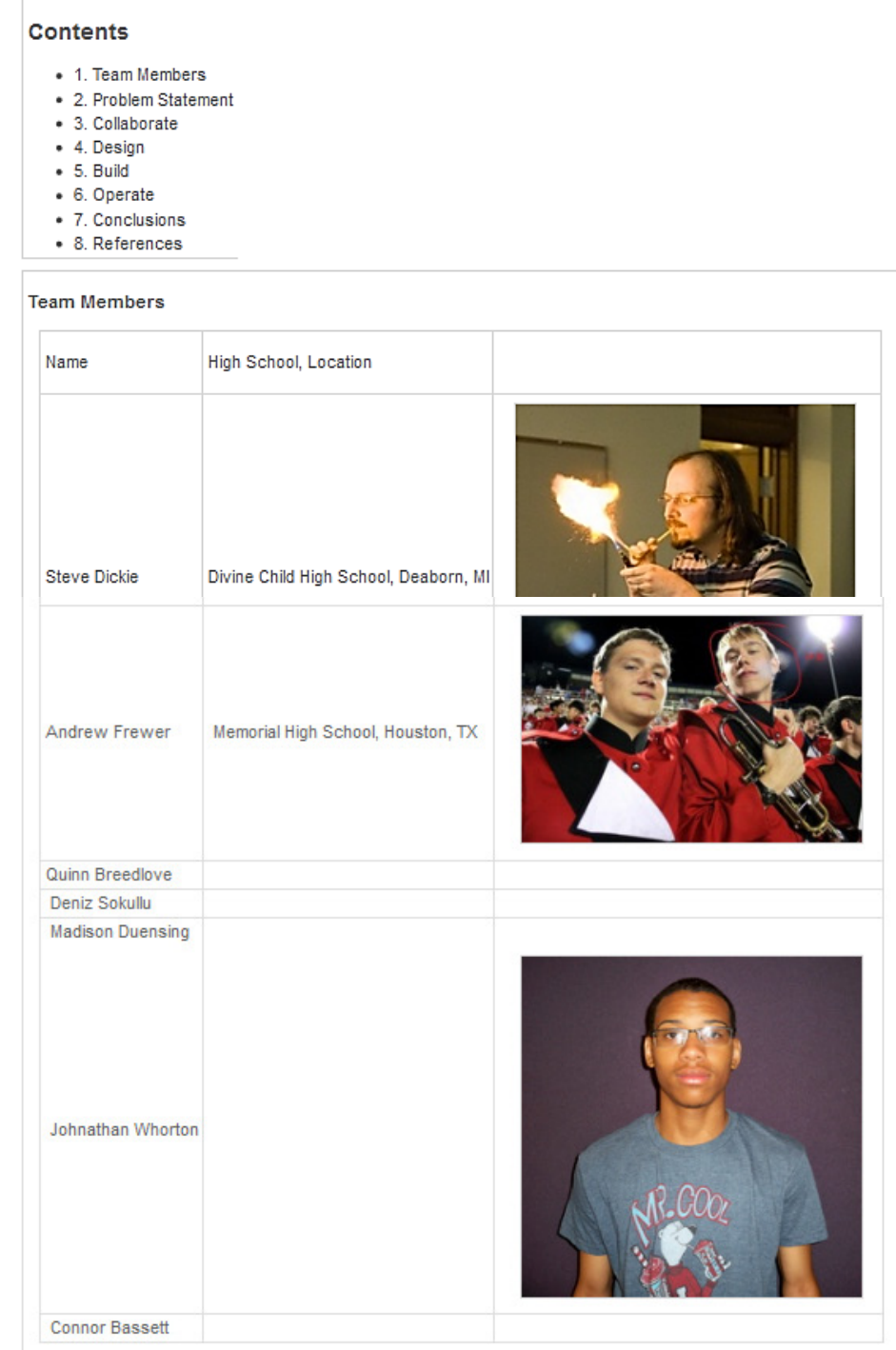

Figure C.7: Team Wiki page (1/3) (contd.)

(Photos printed with permission) 


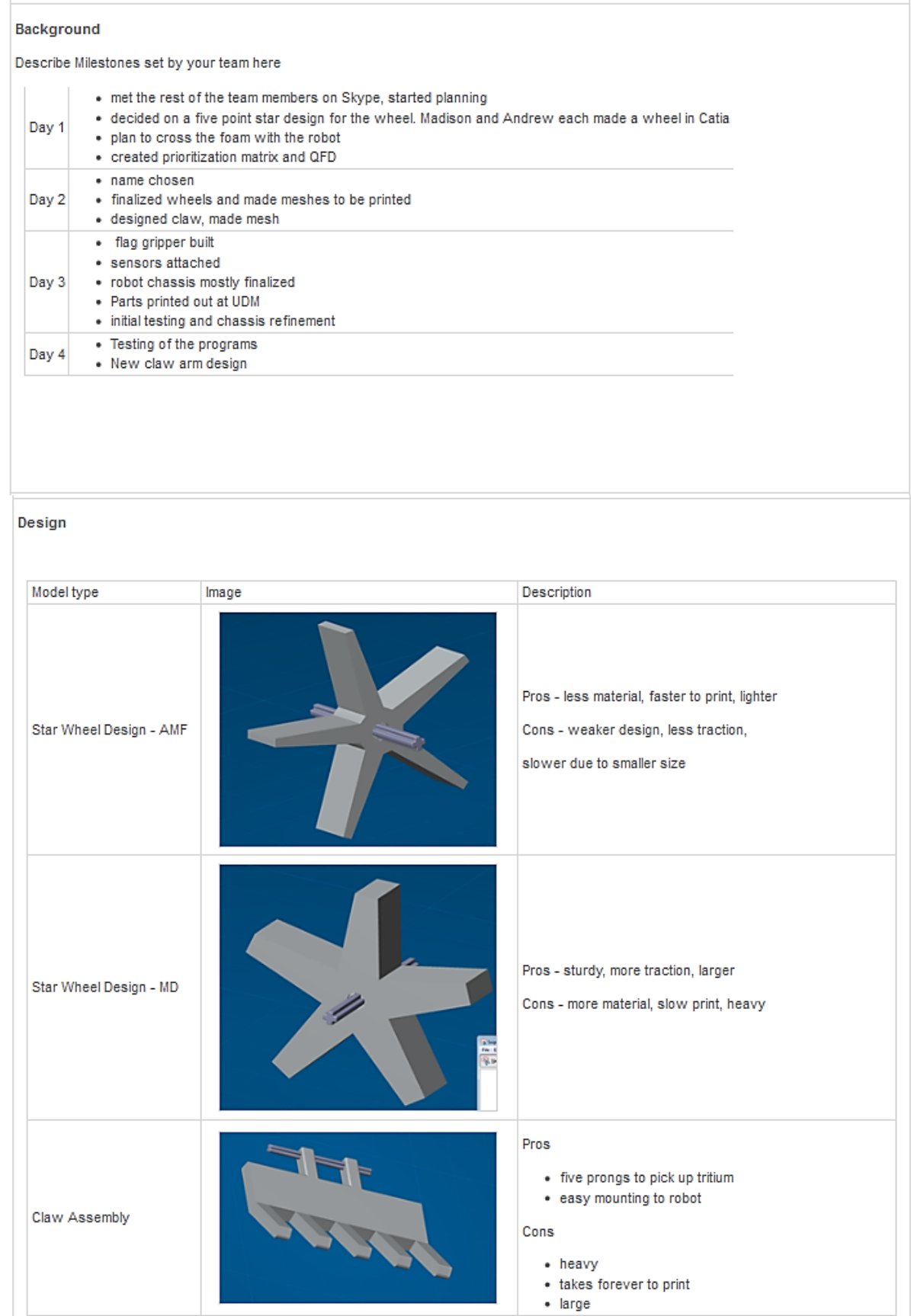

Figure C.7: Team Wiki page (2/3) (contd.) 
Appendix C
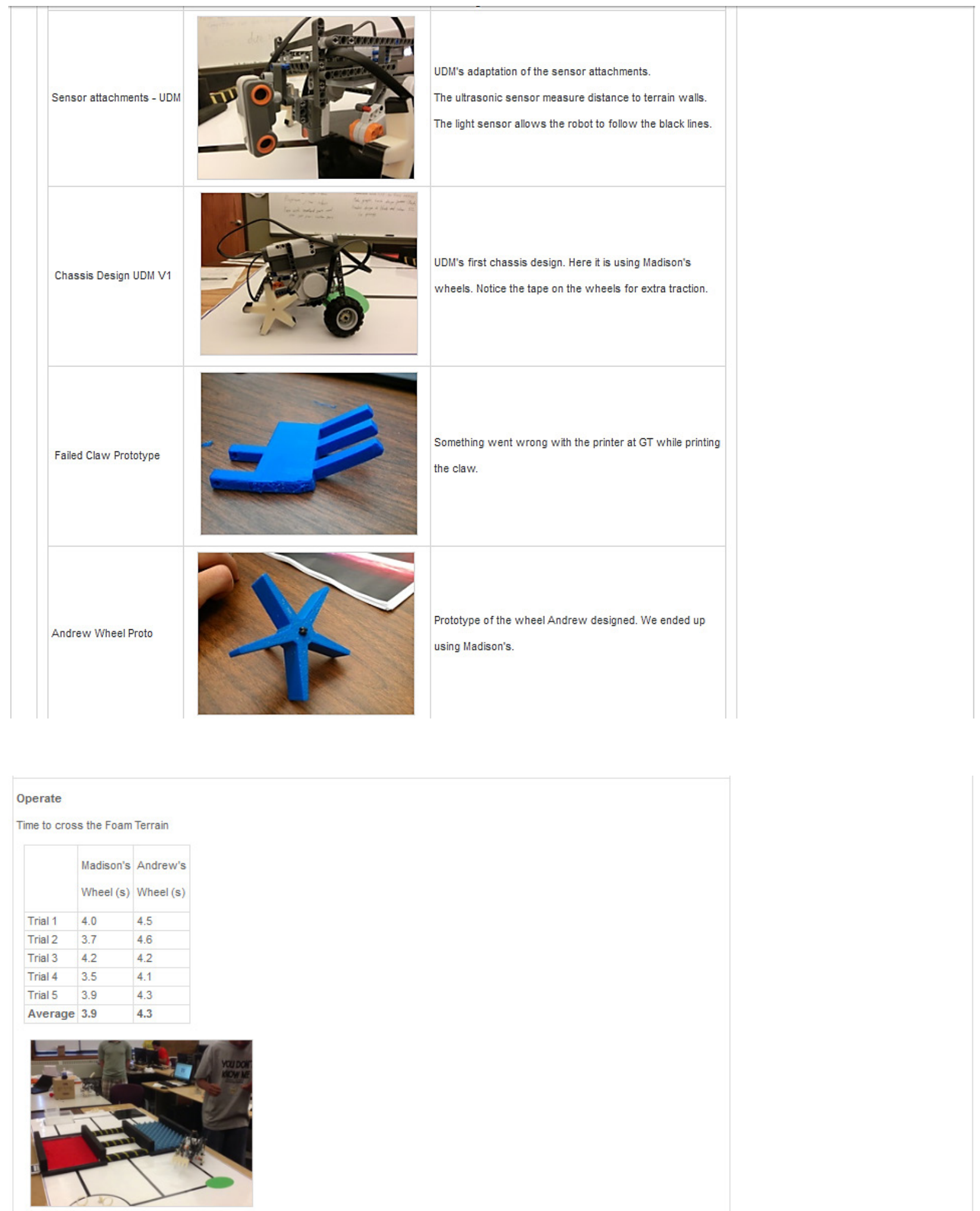

Figure C.7: Team Wiki page (3/3) 


\section{*1. How much do you agree or disagree with each of these statements?}

\begin{tabular}{|c|c|c|c|c|c|}
\hline & Strongly Agree & Agree & Neutral & Disagree & $\begin{array}{l}\text { Strongly } \\
\text { Disagree }\end{array}$ \\
\hline The navigation of the SwYm website was easy. & O & O & $\mathrm{O}$ & $\mathrm{O}$ & O \\
\hline $\begin{array}{l}\text { I was successfully able to use SwYm for collaboration } \\
\text { with other team members. }\end{array}$ & $\mathrm{O}$ & 0 & 0 & 0 & $\mathrm{O}$ \\
\hline $\begin{array}{l}\text { After completing the Blog and Wiki tutorial, I understood } \\
\text { how to use SwYm will be used in the Prize Challenge to } \\
\text { share ideas and information, collaborate on projects, } \\
\text { express opinions, get help and connect with other project } \\
\text { participants. }\end{array}$ & 0 & 0 & 0 & 0 & 0 \\
\hline $\begin{array}{l}\text { The language used in CATIA module was clear and } \\
\text { understandable. }\end{array}$ & 0 & 0 & 0 & 0 & 0 \\
\hline $\begin{array}{l}\text { I was able to easily navigate through the CATIA module } \\
\text { without confusion. }\end{array}$ & 0 & 0 & 0 & 0 & 0 \\
\hline $\begin{array}{l}\text { After completing the CATIA module, I believe I could } \\
\text { successfully design a 2D sketch on my own using the V6 } \\
\text { platform. }\end{array}$ & 0 & 0 & 0 & 0 & 0 \\
\hline $\begin{array}{l}\text { After completing the CATIA module, I believe I could } \\
\text { successfully design a 3D part on my own using the V6 } \\
\text { platform. }\end{array}$ & 0 & 0 & 0 & 0 & 0 \\
\hline
\end{tabular}

\section{Do you have any other feedback about CATIA module or SwYm collaboration website?}

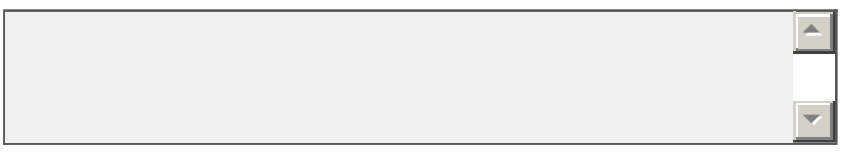




\section{PROGRAM QUALITY}

\section{How much do you agree or disagree with each of these statements?}

The information presented in the modules was
interesting to me.
The online modules provided a useful format for learning
the course concepts.
The online modules presented the engineering concepts
in a clear and understandable manner.
The online modules gave me the knowledge I needed to
participate in the prize challenge.
The program facilitator effectively mentored our group in
the prize challenge.
The SwYm Website was a useful tool for communicating
with other students.

\section{If you answered "STRONGLY DISAGREE" or "DISAGREE" to any of the above statements, please explain why.}




\section{PROGRAM QUALITY}

Please tell us about your experience with the following Prize Challenge components.

\section{*5. Co-create/Collaborate}

Overall, how satisfied were you with the components of

Strongly Agree

Agree

Disagree

Strongly Disagree

the program that allowed you to communicate with

○

$\odot$

O

6

remote partners?

What worked well, and what did not?

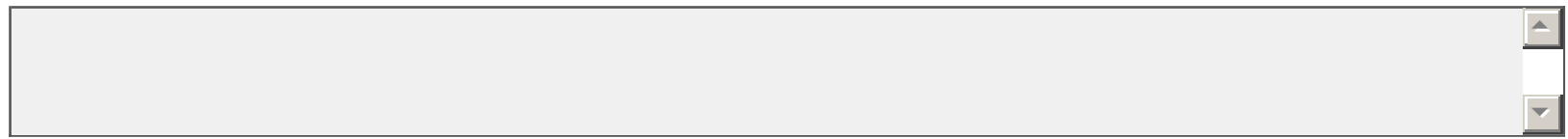

\section{*6. DESIGN}

Overall, how satisfied were you with the components of

the program that allowed you to design a wind

\section{O}

o

turbine/Ground Robot Components?

What worked well, and what did not?

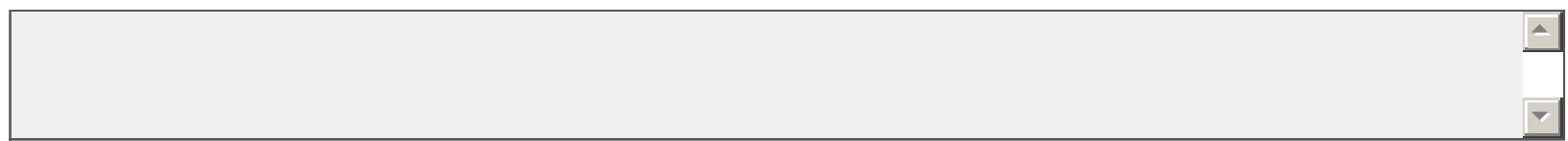

\section{*7. BUILD}

Overall, how satisfied were you with the components of

Strongly Agree

C
Agree

o
Disagree

O
Strongly Disagree

C the program that allowed you to build wind turbine/Ground Robot Components?

What worked well, and what did not?

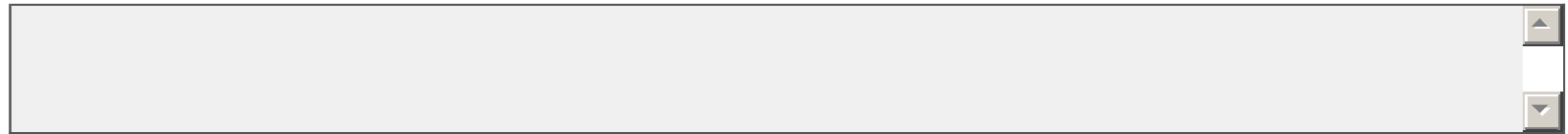

\section{* 8. OPERATE}

\begin{tabular}{l} 
Overall, how satisfied were \\
you with the components of \\
the program that allowed \\
you to participate in the \\
challenges? \\
What worked well, and what did not? \\
\hline
\end{tabular}




\section{LEARNING OBJECTIVES}

What did you learn in this program? Please rate your level of knowledge (with "1" being "very knowledgeable" and " 5 " being "not at all knowledgeable") with the following concepts.

\section{* 9. After finishing this program, how knowledgeable do you feel about...}

\begin{tabular}{|c|c|c|c|c|c|}
\hline & $\begin{array}{c}1 \text { (Very } \\
\text { Knowledgeable) }\end{array}$ & 2 & 3 & 4 & $\begin{array}{c}5 \text { (Not at all } \\
\text { Knowledgeable) }\end{array}$ \\
\hline $\begin{array}{l}\text { Designing parts in CAD and building parts using } 3 D \\
\text { printing/CNC machines. }\end{array}$ & 0 & 0 & 0 & 0 & 0 \\
\hline Operating protypes using customized parts. & 0 & 0 & 0 & 0 & 0 \\
\hline Following and generating assembly instructions. & $\mathrm{O}$ & O & $\mathrm{O}$ & 0 & $\mathrm{O}$ \\
\hline $\begin{array}{l}\text { Showing how to develop and meet milestones } \\
\text { deadlines. }\end{array}$ & 0 & 0 & 0 & 0 & 0 \\
\hline $\begin{array}{l}\text { Showing how manufacturing processes can be scaled } \\
\text { from one prototype unit to many units. }\end{array}$ & 0 & 0 & 0 & 0 & 0 \\
\hline $\begin{array}{l}\text { Explaining the tradeoffs explored in the design for } \\
\text { configuration changes or parametric design space. }\end{array}$ & 0 & 0 & 0 & 0 & 0 \\
\hline
\end{tabular}

\section{*10. Overall, how much do you agree or disagree with each of these statements?}

\section{I enjoyed participating in the program and prize challenge.}

I would like to participate in the program and prize challenge again.

Because of this program, I would like to learn more about engineering design and manufacturing in the future.

Because of this program, I learned more about what engineering design and manufacturing professionals do.
Strongly Agree

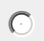

○

C

C
Agree

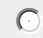

○

C

C
Disagree

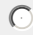

C

C

C
Strongly Disagree

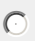

6

○

0 


\section{ATTITUDES ABOUT ENGINEERING}

\section{* 11. How much do you agree or disagree with each of these statements?}

\begin{tabular}{|c|c|c|c|c|c|}
\hline & Strongly Agree & Agree & No Opinion & Disagree & $\begin{array}{l}\text { Strongly } \\
\text { Disagree }\end{array}$ \\
\hline $\begin{array}{l}\text { Engineering is useful in helping solve the problems of } \\
\text { everyday life. }\end{array}$ & 0 & 0 & 0 & 0 & 0 \\
\hline Most people should study some engineering. & 0 & 0 & 0 & 0 & 0 \\
\hline Engineering is helpful for understanding today's world. & 0 & 0 & 0 & 0 & 0 \\
\hline $\begin{array}{l}\text { Engineering is of great importance to a country's } \\
\text { development. }\end{array}$ & 0 & 0 & 0 & 0 & 0 \\
\hline It is important to know engineering to get a good job. & 0 & 0 & 0 & 0 & 0 \\
\hline $\begin{array}{l}\text { Engineers have a chance to make a difference in the } \\
\text { world. }\end{array}$ & O & O & 0 & 0 & O \\
\hline Engineers are respected by people in this country. & 0 & 0 & 0 & 0 & 0 \\
\hline I like engineering classes. & 0 & 0 & 0 & 0 & 0 \\
\hline $\begin{array}{l}\text { I would like to do some extra or unassigned reading in } \\
\text { engineering. }\end{array}$ & 0 & 0 & 0 & 0 & 0 \\
\hline I like the challenge of engineering assignments. & $\mathrm{O}$ & ○ & 0 & O & 0 \\
\hline Engineering is one of my favorite subjects. & O & O & 0 & 0 & 0 \\
\hline I have a real desire to learn engineering. & 0 & 0 & 0 & 0 & O \\
\hline $\begin{array}{l}\text { When I hear the word engineering, I have a feeling of } \\
\text { dislike. }\end{array}$ & 0 & 0 & O & 0 & 0 \\
\hline $\begin{array}{l}\text { I feel tense when someone talks to me about } \\
\text { engineering. }\end{array}$ & 0 & 0 & 0 & 0 & 0 \\
\hline $\begin{array}{l}\text { It makes me nervous to even think about doing } \\
\text { engineering. }\end{array}$ & 0 & 0 & 0 & 0 & 0 \\
\hline It scares me to have to take an engineering class. & 0 & O & O & 0 & O \\
\hline I have a good feeling toward engineering. & 0 & 0 & 0 & 0 & 0 \\
\hline I expect that this program will help me in my & 0 & 0 & 0 & O & O \\
\hline
\end{tabular}




\begin{tabular}{|c|c|c|c|c|}
\hline $\begin{array}{l}\text { Designing, inventing, or developing new products or } \\
\text { tools. }\end{array}$ & $\mathrm{O}$ & $\mathrm{O}$ & $\mathrm{O}$ & O \\
\hline $\begin{array}{l}\text { Discovering new things that help the environment or } \\
\text { people's health. }\end{array}$ & 0 & O & 0 & 0 \\
\hline Using computers, lab equipment, or other technology. & $\mathrm{O}$ & O & 0 & 0 \\
\hline Having your work reviewed and critiqued by others. & 0 & O & 0 & O \\
\hline
\end{tabular}


Table D1: Student beliefs regarding program quality.

Students were asked to indicate how much they agree or disagree with the following statements:

\begin{tabular}{|c|c|c|c|c|c|c|}
\hline Statement & & \multicolumn{4}{|c|}{ Student Response (\%) } \\
\hline $\begin{array}{c}\text { The information presented in } \\
\text { me. } \\
\text { the modules was interesting to } \\
\text { me }\end{array}$ & 30 & 3.20 & $23.33 \%$ & $73.33 \%$ & $3.33 \%$ & $0.00 \%$ \\
\hline $\begin{array}{c}\text { The online modules provided a } \\
\text { useful format for learning the } \\
\text { course concepts. }\end{array}$ & 30 & 3.20 & $26.67 \%$ & $66.67 \%$ & $6.67 \%$ & $0.00 \%$ \\
\hline $\begin{array}{c}\text { The online modules presented } \\
\text { the engineering concepts in a } \\
\text { clear and understandable } \\
\text { manner. }\end{array}$ & 30 & 3.10 & $13.33 \%$ & $83.33 \%$ & $3.33 \%$ & $0.00 \%$ \\
\hline $\begin{array}{c}\text { The online modules gave me } \\
\text { the knowledge I needed to } \\
\text { participate in the prize } \\
\text { challenge. }\end{array}$ & 30 & 3.13 & $23.33 \%$ & $70.00 \%$ & $3.33 \%$ & $3.33 \%$ \\
\hline $\begin{array}{c}\text { The program facilitator } \\
\text { effectively mentored our group } \\
\text { in the prize challenge. }\end{array}$ & 30 & 3.07 & $23.33 \%$ & $66.67 \%$ & $3.33 \%$ & $6.67 \%$ \\
\hline $\begin{array}{c}\text { The SwYm website was a } \\
\text { useful tool for communicating } \\
\text { with other students. }\end{array}$ & 30 & 2.90 & $16.67 \%$ & $60.00 \%$ & $20.00 \%$ & $3.33 \%$ \\
\hline
\end{tabular}

Mean scores reflect the following values for each response category:

1: Strongly Disagree 2: Disagree 3: Agree 4: Strongly Agree 
Table D2: Student Beliefs Regarding SwYm and CATIA modules

Students were asked how much they agree or disagree with the following statements:

\begin{tabular}{|c|c|c|c|c|c|c|c|}
\hline & & \multicolumn{6}{|c|}{ Student Response (\%) } \\
\hline Statement & $\mathbf{N}$ & Mean & $\begin{array}{c}\text { Strongly } \\
\text { Agree }\end{array}$ & Agree & Neutral & Disagree & $\begin{array}{l}\text { Strongly } \\
\text { Disagree }\end{array}$ \\
\hline $\begin{array}{l}\text { The navigation of the } \\
\text { SwYm website was } \\
\text { easy. }\end{array}$ & 30 & 3.90 & $16.67 \%$ & $66.67 \%$ & $6.67 \%$ & $10.00 \%$ & $0.00 \%$ \\
\hline $\begin{array}{c}\text { I was successfully able } \\
\text { to use SwYm for } \\
\text { collaboration with } \\
\text { other team members. }\end{array}$ & 30 & 4.00 & $16.67 \%$ & $70.00 \%$ & $10.00 \%$ & $3.33 \%$ & $0.00 \%$ \\
\hline $\begin{array}{l}\text { After completing the } \\
\text { blog and Wiki tutorial, } \\
\text { I understood how to } \\
\text { use SwYm in the Prize } \\
\text { Challenge to share } \\
\text { ideas and information, } \\
\text { collaborate on projects, } \\
\text { express opinions, get } \\
\text { help and connect with } \\
\text { other project } \\
\text { participants. }\end{array}$ & 30 & 3.57 & $13.33 \%$ & $43.33 \%$ & $33.33 \%$ & $6.67 \%$ & $3.33 \%$ \\
\hline $\begin{array}{c}\text { The language used in } \\
\text { CATIA module was } \\
\text { clear and } \\
\text { understandable. }\end{array}$ & 30 & 3.67 & $10.00 \%$ & $56.67 \%$ & $23.33 \%$ & $10.00 \%$ & $0.00 \%$ \\
\hline $\begin{array}{l}\text { I was able to easily } \\
\text { navigate through the } \\
\text { CATIA module } \\
\text { without confusion. }\end{array}$ & 29 & 3.45 & $13.79 \%$ & $48.28 \%$ & $13.79 \%$ & $17.24 \%$ & $6.90 \%$ \\
\hline $\begin{array}{l}\text { After completing the } \\
\text { CATIA module, I } \\
\text { believe I could } \\
\text { successfully design a } \\
\text { 2D sketch on my own } \\
\text { using the V6 platform. }\end{array}$ & 30 & 4.53 & $60.00 \%$ & $33.33 \%$ & $6.67 \%$ & $0.00 \%$ & $0.00 \%$ \\
\hline $\begin{array}{l}\text { After completing the } \\
\text { CATIA module, I } \\
\text { believe I could } \\
\text { successfully design a } \\
\text { 3D part on my own } \\
\text { using the V6 platform. }\end{array}$ & 30 & 4.37 & $53.33 \%$ & $33.33 \%$ & $10.00 \%$ & $3.33 \%$ & $0.00 \%$ \\
\hline
\end{tabular}

Reported mean scores reflect the following values for each response category:

1: Strongly Disagree 2: Disagree 3: Neutral 4: Agree 5: Strongly Agree 
Table D3: After finishing this program, how knowledgeable do you feel about:

\begin{tabular}{|c|c|c|c|c|c|c|c|}
\hline & & \multicolumn{6}{|c|}{ Student Response (\%) } \\
\hline Learning Objective & $\mathbf{N}$ & Mean & $\begin{array}{l}5 \text { (Very } \\
\text { Knowle } \\
\text { dgeable) }\end{array}$ & 4 & 3 & 2 & $\begin{array}{c}1 \text { (Not at } \\
\text { all } \\
\text { knowled } \\
\text { geable) }\end{array}$ \\
\hline $\begin{array}{l}\text { Designing parts in } \\
\text { CAD and building } \\
\text { parts using 3D } \\
\text { printing/CNC } \\
\text { machines. } \\
\end{array}$ & 29 & 4.10 & $31.03 \%$ & $48.28 \%$ & $20.69 \%$ & $0.00 \%$ & $0.00 \%$ \\
\hline $\begin{array}{l}\text { Operating prototypes } \\
\text { using customized parts. }\end{array}$ & 29 & 3.90 & $24.14 \%$ & $51.72 \%$ & $17.24 \%$ & $3.45 \%$ & $3.45 \%$ \\
\hline $\begin{array}{c}\text { Following and } \\
\text { generating assembly } \\
\text { instructions. }\end{array}$ & 29 & 4.07 & $31.03 \%$ & $48.28 \%$ & $17.24 \%$ & $3.45 \%$ & $0.00 \%$ \\
\hline $\begin{array}{c}\text { Collaborating with a } \\
\text { distant team partner } \\
\text { using virtual } \\
\text { collaboration tools. } \\
\end{array}$ & 29 & 4.03 & $37.93 \%$ & $41.38 \%$ & $10.34 \%$ & $6.90 \%$ & $3.45 \%$ \\
\hline $\begin{array}{c}\text { Showing how to } \\
\text { develop and meet } \\
\text { milestone deadlines. }\end{array}$ & 29 & 3.83 & $27.59 \%$ & $37.93 \%$ & $24.14 \%$ & $10.34 \%$ & $0.00 \%$ \\
\hline $\begin{array}{c}\text { Showing how } \\
\text { manufacturing } \\
\text { processes can be scaled } \\
\text { from one prototype } \\
\text { unit to many units. }\end{array}$ & 29 & 3.72 & $13.79 \%$ & $58.62 \%$ & $13.79 \%$ & $13.79 \%$ & $0.00 \%$ \\
\hline $\begin{array}{c}\text { Integrating the parts of } \\
\text { an electro-mechanical } \\
\text { system (i.e. wind } \\
\text { turbine). }\end{array}$ & 29 & 3.79 & $27.59 \%$ & $48.28 \%$ & $10.34 \%$ & $3.45 \%$ & $10.34 \%$ \\
\hline $\begin{array}{c}\text { Explaining the } \\
\text { tradeoffs explored in } \\
\text { the design for simple } \\
\text { components/complex } \\
\text { assembly versus } \\
\text { complex } \\
\text { components/simple } \\
\text { assembly. }\end{array}$ & 29 & 3.83 & $27.59 \%$ & $41.38 \%$ & $20.69 \%$ & $6.90 \%$ & $3.45 \%$ \\
\hline $\begin{array}{l}\text { Explaining the } \\
\text { tradeoffs explored in } \\
\text { the design for } \\
\text { configuration changes } \\
\text { or parametric design } \\
\text { space. }\end{array}$ & 29 & 3.69 & $24.14 \%$ & $34.48 \%$ & $31.03 \%$ & $6.90 \%$ & $3.45 \%$ \\
\hline
\end{tabular}


Table D4: Overall, how much do you agree or disagree with each of these statements?

\begin{tabular}{|c|c|c|c|c|c|c|}
\hline & & \multicolumn{5}{|c|}{ Student Response (\%) } \\
\hline Statement & $\mathbf{N}$ & Mean & $\begin{array}{c}\text { Strongly } \\
\text { Agree }\end{array}$ & Agree & Disagree & $\begin{array}{c}\text { Strongly } \\
\text { Disagree }\end{array}$ \\
\hline $\begin{array}{c}\text { I enjoyed participating in the } \\
\text { program and prize challenge. }\end{array}$ & 29 & 3.34 & $41.38 \%$ & $51.72 \%$ & $6.90 \%$ & $0.00 \%$ \\
\hline $\begin{array}{c}\text { I would like to participate in } \\
\text { the program and prize } \\
\text { challenge again. }\end{array}$ & 29 & 3.21 & $34.48 \%$ & $51.72 \%$ & $13.79 \%$ & $0.00 \%$ \\
\hline $\begin{array}{c}\text { Because of this program, I } \\
\text { would like to learn more about } \\
\text { engineering design and } \\
\text { manufacturing in the future. }\end{array}$ & 29 & 3.38 & $48.28 \%$ & $44.83 \%$ & $3.45 \%$ & $3.45 \%$ \\
\hline $\begin{array}{c}\text { Because of this program, I } \\
\text { learned more about what } \\
\text { engineering design and }\end{array}$ & 29 & 3.41 & $51.72 \%$ & $41.38 \%$ & $3.45 \%$ & $3.45 \%$ \\
\hline \hline $\begin{array}{c}\text { manufacturing professionals } \\
\text { do. }\end{array}$ & & & & & & \\
\hline
\end{tabular}

Mean scores reflect the following values for each response category:

1: Strongly Disagree 2: Disagree 3: Agree 4: Strongly Agree 
Table D5: Overall, how much do you agree or disagree with each of these statements?

\begin{tabular}{|c|c|c|c|c|c|c|c|}
\hline & & \multicolumn{6}{|c|}{ Student Response (\%) } \\
\hline Statement & $\mathbf{N}$ & Mean & $\begin{array}{l}5 \text { (Very } \\
\text { Knowle } \\
\text { dgeable) }\end{array}$ & 4 & 3 & 2 & $\begin{array}{c}1 \text { (Not at } \\
\text { all } \\
\text { knowled } \\
\text { geable) }\end{array}$ \\
\hline $\begin{array}{c}\text { Engineering is useful in } \\
\text { helping solve the } \\
\text { problems of everyday } \\
\text { life. }\end{array}$ & 28 & 4.50 & $60.71 \%$ & $28.57 \%$ & $10.71 \%$ & $0.00 \%$ & $0.00 \%$ \\
\hline $\begin{array}{l}\text { Most people should } \\
\text { study some } \\
\text { engineering. }\end{array}$ & 28 & 3.96 & $25.00 \%$ & $53.37 \%$ & $14.29 \%$ & $7.14 \%$ & $0.00 \%$ \\
\hline $\begin{array}{l}\text { Engineering is helpful } \\
\text { for understanding } \\
\text { today's world. }\end{array}$ & 28 & 4.32 & $46.43 \%$ & $42.86 \%$ & $7.14 \%$ & $3.57 \%$ & $0.00 \%$ \\
\hline $\begin{array}{l}\text { Engineering is of great } \\
\text { importance to a } \\
\text { country's development. }\end{array}$ & 28 & 4.64 & $67.86 \%$ & $28.57 \%$ & $3.57 \%$ & $0.00 \%$ & $0.00 \%$ \\
\hline $\begin{array}{l}\text { It is important to know } \\
\text { engineering to get a } \\
\text { good job. }\end{array}$ & 28 & 3.50 & $21.43 \%$ & $32.14 \%$ & $28.57 \%$ & $10.71 \%$ & $7.14 \%$ \\
\hline $\begin{array}{c}\text { Engineers have a } \\
\text { chance to make a } \\
\text { difference in the world. }\end{array}$ & 28 & 4.46 & $50.00 \%$ & $46.43 \%$ & $3.57 \%$ & $0.00 \%$ & $0.00 \%$ \\
\hline $\begin{array}{c}\text { Engineers are } \\
\text { respected by people in } \\
\text { this country. }\end{array}$ & 28 & 3.89 & $25.00 \%$ & $50.00 \%$ & $17.86 \%$ & $3.57 \%$ & $3.57 \%$ \\
\hline $\begin{array}{l}\text { I like engineering } \\
\text { classes. }\end{array}$ & 28 & 4.43 & $50.00 \%$ & $42.86 \%$ & $7.14 \%$ & $0.00 \%$ & $0.00 \%$ \\
\hline $\begin{array}{l}\text { I would like to do some } \\
\text { extra or unassigned } \\
\text { reading in engineering. }\end{array}$ & 28 & 4.07 & $25.00 \%$ & $60.71 \%$ & $10.71 \%$ & $3.57 \%$ & $0.00 \%$ \\
\hline
\end{tabular}


Table D5(contd.): Overall, how much do you agree or disagree with each of these statements?

\begin{tabular}{|c|c|c|c|c|c|c|c|}
\hline & & \multicolumn{6}{|c|}{ Student Response (\%) } \\
\hline Statement & $\mathbf{N}$ & Mean & $\begin{array}{l}5 \text { (Very } \\
\text { Knowle } \\
\text { dgeable) }\end{array}$ & 4 & 3 & 2 & $\begin{array}{c}1 \text { (Not at } \\
\text { all } \\
\text { knowled } \\
\text { geable) }\end{array}$ \\
\hline $\begin{array}{l}\text { I like the challenge of } \\
\text { engineering } \\
\text { assignments. }\end{array}$ & 28 & 4.32 & $35.71 \%$ & $60.71 \%$ & $3.57 \%$ & $0.00 \%$ & $0.00 \%$ \\
\hline $\begin{array}{l}\text { Engineering is one of } \\
\text { my favorite subjects. }\end{array}$ & 28 & 4.32 & $46.43 \%$ & $42.86 \%$ & $7.14 \%$ & $3.57 \%$ & $0.00 \%$ \\
\hline $\begin{array}{l}\text { I have a real desire to } \\
\text { learn engineering. }\end{array}$ & 28 & 4.36 & $42.86 \%$ & $50.00 \%$ & $7.14 \%$ & $0.00 \%$ & $0.00 \%$ \\
\hline $\begin{array}{l}\text { When I hear the word } \\
\text { engineering, I have a } \\
\text { feeling of dislike. }\end{array}$ & 28 & 2.29 & $3.57 \%$ & $28.57 \%$ & $3.57 \%$ & $21.43 \%$ & $42.86 \%$ \\
\hline $\begin{array}{l}\text { I feel tense when } \\
\text { someone talks to me } \\
\text { about engineering. }\end{array}$ & 28 & 2.46 & $3.57 \%$ & $32.14 \%$ & $3.57 \%$ & $28.57 \%$ & $32.14 \%$ \\
\hline $\begin{array}{l}\text { It makes me nervous to } \\
\text { even think about doing } \\
\text { engineering. }\end{array}$ & 28 & 2.39 & $7.14 \%$ & $28.57 \%$ & $3.57 \%$ & $17.86 \%$ & $42.86 \%$ \\
\hline $\begin{array}{l}\text { It scares me to have to } \\
\text { take an engineering } \\
\text { class. }\end{array}$ & 28 & 2.32 & $7.14 \%$ & $25.00 \%$ & $3.57 \%$ & $21.43 \%$ & $42.86 \%$ \\
\hline $\begin{array}{l}\text { I have a good feeling } \\
\text { toward engineering. }\end{array}$ & 28 & 4.32 & $39.29 \%$ & $53.57 \%$ & $7.14 \%$ & $0.00 \%$ & $0.00 \%$ \\
\hline
\end{tabular}


Table D6: How interested would you be in having a job where you would do the following activities?

\begin{tabular}{|c|c|c|c|c|c|c|}
\hline Statement & & \multicolumn{4}{|c|}{ Student Response (\%) } \\
\hline $\begin{array}{c}\text { Designing, inventing, or } \\
\text { developing new products or } \\
\text { tools. }\end{array}$ & 28 & 3.46 & $53.57 \%$ & $39.29 \%$ & $7.14 \%$ & $0.00 \%$ \\
Agree & & & & & & \\
\hline $\begin{array}{c}\text { Spending a lot of time and } \\
\text { energy on a problem until you } \\
\text { solve it. }\end{array}$ & 28 & 3.29 & $42.86 \%$ & $46.43 \%$ & $7.14 \%$ & $3.57 \%$ \\
\hline $\begin{array}{c}\text { Discovering new things that } \\
\text { help the environment or } \\
\text { people's health. }\end{array}$ & 28 & 3.26 & $44.44 \%$ & $37.04 \%$ & $18.52 \%$ & $0.00 \%$ \\
\hline $\begin{array}{c}\text { Using computers, lab } \\
\text { equipment, or other } \\
\text { technology. }\end{array}$ & 28 & 3.46 & $57.14 \%$ & $35.71 \%$ & $3.57 \%$ & $3.57 \%$ \\
\hline $\begin{array}{c}\text { Conducting investigations to } \\
\text { understand how the world } \\
\text { works. }\end{array}$ & 28 & 3.39 & $50.00 \%$ & $39.29 \%$ & $10.71 \%$ & $0.00 \%$ \\
\hline $\begin{array}{c}\text { Analyzing data to draw } \\
\text { conclusions. }\end{array}$ & 28 & 3.11 & $32.14 \%$ & $50.00 \%$ & $14.29 \%$ & $3.57 \%$ \\
\hline $\begin{array}{c}\text { Having your work reviewed } \\
\text { and critiqued by others. }\end{array}$ & 28 & 3.00 & $17.86 \%$ & $64.29 \%$ & $17.86 \%$ & $0.00 \%$ \\
\hline
\end{tabular}

Mean scores reflect the following values for each response category:

1: Not at all interested 2: Only a little interested 3: Fairly interested 4: Very interested 